\title{
Corporate Governance and Value Creation: Evidence from Private Equity ${ }^{1}$
}

\section{by}

\author{
Viral V. Acharya, Moritz Hahn and Conor Kehoe
}

First draft: 7 April 2008

This draft: 2 January 2009

\author{
Contact information:
}

Viral V. Acharya

London Business School, NYU-Stern and CEPR

Stern School of Business, 44 West $4^{\text {th }}$ St, New York, NY 10012

Tel: +1 2129980354

e-mail: vacharya@stern.nyu.edu

\author{
Moritz Hahn \\ Ludwig-Maximilians-University Munich \\ Ludwigstr. 28 / 012, 80333 Munich, Germany \\ Tel: +49 (0)89 21086935 \\ e-mail: moritz.hahn@lrz.uni-muenchen.de \\ Conor Kehoe \\ McKinsey \& Company, Inc. \\ 1 Jermyn Street, London - SW1Y 4UH, UK \\ Tel: +44 (0)20 79615988 \\ e-mail: Conor_Kehoe@mckinsey.com
}

\footnotetext{
${ }^{1}$ A part of this study was undertaken while Viral Acharya was visiting Stanford-GSB. All errors remain our own. We are especially grateful to the PE firms who assembled and gave us access to sensitive deal data. Viral Acharya was supported during this study by the London Business School Governance Center and Private Equity Institute, the Leverhulme Foundation, INQUIRE Europe, and London Business School's Research and Materials Development (RAMD) grant. McKinsey \& Company has also devoted significant human resource to carrying out the fieldwork and analysis, not for any client but on its own account. We are grateful to excellent assistance and management of data collection and interviews by Amith Karan, Ricardo Martinelli, Prashanth Reddy and David Wood of McKinsey \& Co. Ramin Baghai-Wadji, Ann Iveson, Hanh Le, Chao Wang and Yili Zhang also provided valuable research assistance. The study has benefited from comments of Steve Kaplan (discussant), Tim Kelly (discussant) and seminar participants at European Central Bank and Centre for Financial Studies Conference in Frankfurt, Inaugural Symposium at London Business School Coller Institute of Private Equity, University of Chicago and University of Illinois at Chicago joint conference, London Business School, McKinsey \& Co. and participating PE firms. All errors remain our own.
} 


\title{
Corporate Governance and Value Creation: Evidence from Private Equity
}

\begin{abstract}
We examine deal-level data on private equity transactions in the UK initiated during the period 1996 to 2004 by mature private equity houses. We un-lever the deal-level equity return and adjust for (un-levered) return to quoted peers to extract a measure of "alpha" or abnormal performance of the deal. The alpha is significantly positive on average and robust during sector downturns. In the cross-section of deals, higher alpha is related to greater improvement in EBITDA to Sales ratio (margin) and greater growth in EBITDA multiple during the private phase, relative to that of quoted peers. In particular, deals with higher alpha either grow their margins more substantially, and/or grow multiples more substantially, whilst expanding their revenues only in line with the sector. Based on interviews with general partners involved with the deals, we find that deals with higher alpha and higher margin growth are associated with greater intensity of engagement of private equity houses during the early phase of the deal, employment of value-creation initiatives for productivity and organic growth, and complementing top management with external support. Overall, our results are consistent with mature private equity houses creating value for portfolio companies through active ownership and governance.
\end{abstract}

JEL: G31, G32, G34, G23, G24.

Keywords: leveraged buyouts (LBO), management buyouts (MBO), active ownership, activism, management turnover, alpha 


\section{Introduction}

In a seminal piece on private equity, Jensen (1989) argued that leveraged buyouts (LBOs) create value through high leverage and powerful incentives. He proposed that the public form of the corporation is often characterized by entrenched management that is prone to cash-flow diversion and averse to taking on efficient levels of risk. Consistent with Jensen’s view, Kaplan (1989), Smith (1990), Lichtenberg and Siegel (1990), and others provide evidence that LBOs do create value by significantly improving the operating performance of acquired companies and by disgorging cash in the form of high debt payments

The recent literature has focused instead on the returns that private equity (PE) funds - which usually initiate the LBO and own (or manage, to be precise) at least a majority of the resulting private entity - generate for their end investors such as pension funds. In particular, Kaplan and Schoar (2005) studied internal rates of return (IRRs) net of management fees for 746 funds during 1985-2001 and found that the median fund generated only $80 \%$ of S\&P500 return and the mean was only slightly higher, at around $90 \% .^{2}$ The evidence is, however, better for the largest and most mature houses (those that have been around for at least 5 years). Kaplan and Schoar document that, for funds in this sub-set of PE houses, the median performance is $150 \%$ of S\&P500 return and the mean is even higher at $170 \%$. Furthermore, this performance is persistent, a characteristic that is generally associated with potential existence of "skill” in a fund manager. Notably, such persistence has not been found in mutual funds and when found has generally been in the worst performers (Carhart, 1997).

Our paper is an attempt to bridge these two strands of literature concerning private equity, the first of which analyses the operating performance of acquired companies, and the second analyzes fund IRRs. We focus on the following questions: (1) Are the returns to large,

\footnotetext{
${ }^{2}$ This evidence has been confirmed by studies in Europe (see Related Literature), although some believe these numbers are at best rosy given survivorship biases in data employed. This by itself does not necessarily refute Jensen's original claim: It could simply be that PE funds keep through fees the value they create. The puzzle that the evidence on median return of PE funds raises is thus more about why their investors (the limited partners) choose to invest in this asset class as a whole, an issue investigated by Lerner and Schoar (2004) and Lerner, Schoar and Wong (2007).
} 
mature PE houses simply due to financial gearing over and above gearing in the comparable quoted sector, or do these returns represent the value created in enterprises they engage with, over and above the value created by the quoted sector peers? (2) What is the effect of PE ownership on the operating performance of portfolio companies relative to that of quoted peers, and how does this performance relate to the financial value created (if any) by these houses? (3) What are the distinguishing characteristics of the governance and operational approach of these PE houses relative to those of the PLC boards, and which of these characteristics are best associated with value creation? In particular, we are interested in taking a step beyond Jensen's hypothesis by investigating whether large, mature PE houses create enterprise value by engaging in "active” ownership or governance and operational engineering, in addition to employing leverage and powerful incentives.

(1) To answer the first question, we develop a methodology to decompose the deallevel equity return earned by a PE house, measured by the IRR, into two components: the unlevered return and amplification of this un-levered return by deal leverage. Next, we extract a benchmark (un-levered) return that the quoted peers of the deal generated over the life of the deal. The difference between these two un-levered returns is what we call "alpha”, a measure of enterprise-level abnormal performance of the deal relative to its quoted peers; that is, after purging the effects of financial leverage. We posit, and later verify, that the alpha of a deal captures the return associated with operational strategies and governance changes. ${ }^{3}$

We apply this methodology to 66 large deals (greater than $€ 100 \mathrm{mln}$ in enterprise value) in the UK from 12 mature PE houses initiated over the period 1996 to $2004 .^{4}$ We find that, on average, about $20-30 \%$ of average deal IRR comes from the alpha, another $25-35 \%$ is due to amplification of alpha by financial leverage, the remaining being due to exposure to the quoted sector (that is, due to sector-picking ability or simply due to luck) and leverage

\footnotetext{
${ }^{3}$ The leverage amplification can also be further decomposed into amplification due to deal leverage on the quoted peers' return and amplification on alpha. Since such alpha also contains (idiosyncratic) risk at the deal level, the leverage amplification on alpha can be interpreted as financial leverage amplifying the operating risk of the deal.
} 
amplification on this. Although alpha has substantial variation across deals, it is on average positive and statistically significant, consistent with the view that large, mature PE houses generate higher (enterprise-level) returns compared to benchmarks.

In the cross-section and time-series, alpha has several interesting properties. First, alpha is positively, even if imperfectly, related to IRR and variants of the "public-market equivalent” (PME) measures based on Kaplan and Schoar (2005). Second, alpha appears robust to sector downturns. In fact, it is stronger during sector downturns. When we identify deals where the quoted sector delivered negative total return to shareholders over the life of the deal, we find that alpha for this sub-sample of deals is about three times as large as that for the overall sample. Without this alpha, these deals would not have generated positive IRRs.

(2) Regarding the second question we raised at the outset, about whether alpha is related to value creation in terms of operational improvements, we show that this is indeed the case, and hence that alpha is not merely an artefact of our return attribution methodology. We start the analysis by identifying the impact of PE ownership on the operating performance of portfolio companies relative to that of the sector. Beforehand we compare each deal with the corresponding sector in terms of its pre-acquisition operating performance. We find that PEowned companies are not a random selection from the sector in terms of pre-acquisition operating measures. On average the targeted companies are significantly smaller in sales, EBITDA, enterprise value, and number of employees. In fact their size is only a fraction of the sector averages. Interestingly, targeted companies show a statistically significant higher profitability, which might be explained by the inverse relationship between sales size and profitability generally found in data. However, we find no difference between the deals and their respective sectors in performance trends pre-acquisition (from year -2 to the last year before acquisition). Both targeted and sector companies show nearly the same robust increase in nominal sales and constant profitability. Since the strict exogeneity assumption of PE

\footnotetext{
${ }^{4}$ We believe this time period is particularly well-suited for studying value creation through operational engineering. Kaplan and Stromberg (2008) note that operational engineering became a key private equity input to portfolio companies primarily in the last decade.
} 
ownership is not violated, we test for a causal impact of PE ownership on operating performance in a univariate and additionally in a difference-in-difference regression setting.

We find that PE ownership causes the deal margin (EBITDA/Sales) to increase by on average around $4 \%$ relative to that during the pre-acquisition phase and controlling for holding length (duration). This impact stays significant even when we add dummies for bankruptcies, un-exited deals, inorganic deals (deals without significant acquisition or divestment activity) and sales growth. Interestingly, the duration reduces this impact by about $0.8 \%$ per year of holding. Our interpretation of this finding is not that PE becomes counterproductive after a while; instead we think that PE houses tend to stick to dogs (underperforming deals) longer and wait for better times to sell. Taking this negative duration effect into account, the average PE impact on margins for (in)organic deals is in total around 1.5-2.0\% (0.7-1.4\%), given an average holding length of 3 (4) years. Surprisingly, but in line with the finding that alpha is the highest when the sector return is negative, a decreasing sector margin in fact has a positive impact on the deal margin. All deals, in particular the inorganic ones, out-perform their sectors on average in terms of growth in Enterprise Value to EBITDA multiple. While this could be the effect of sustainable margin improvements, which buyers pay for at the time of deal exit, it could also simply be linked to "selling high" since we have some evidence that PE houses hold on longer to dogs. ${ }^{5}$

Finally, we find that in the cross-section of deals, higher alpha is associated with stronger PE operating out-performance relative to quoted peers, and especially with greater improvements in the margin and the EBITDA multiple. Exactly those measures show up as important for alpha, for which we found a casual PE ownership impact before. The improvements in margins and multiples are robust determinants of alpha, in particular, they are robust to controlling for deal duration, size, deal type (inorganic or organic), and dummies

\footnotetext{
${ }^{5}$ In contrast to perceived wisdom, especially in the media, we do not find that deals in our sample are subject to asset-stripping: in fact, they grow their revenue at least as much as the quoted peers; they increase employment - though not as much as their peers, but improve profitability margins relative to peers.
} 
for various acquisition time sub-periods (that control for trends in cost of debt finance and stock-market valuations).

(3) Answering the last question constitutes the most important and novel step of our analysis. We conducted 48 in-depth interviews with general partners (GPs) involved in our deals, essentially wherever the relevant GPs had not left the PE house in question. In order to put more structure into the collected interview information, we identified 21 questions to which the answers implied either relatively active or inactive governance. Each answer was awarded a score of either 100 (active) or 0 (inactive), and the 21 questions were compiled into seven groups, each containing three related questions. The seven groups are as follows: (1) Changed top management (CEO, CFO, etc.) within the $1^{\text {st }} 100$ days; (2) Launched multiple initiatives for value creation; (3) Shaped value creation plan; (4) Provided management support, especially in the $1^{\text {st }} 100$ days; (5) Provided strong incentives (how high-powered in terms of equity ownership, to what level of employees, and how sensitive to threshold performance indicators); (6) Created an efficient board structure (smaller, few non-executive directors or NXDs excluding GPs and separation of CEO and Chairman); and finally (7) Leveraged external support.

In a multivariate regression analysis that links these governance scores to alpha and operating performance, we find that PE houses generate higher alphas for those deals for which they a) frequently interacted with management (especially in the $1^{\text {st }} 100$ days) and b) leveraged external support. Overall it seems that PE houses overcome the difficulties in principal-agent relationships with an "encourage and challenge" approach, since a) and b) includes a support as well as a monitoring dimension. This is suggestive of the critical agency problem that may be unlocked by successful PE houses for value creation through challenging entrenched management in PLCs, taking private and monitoring the inefficiently run subsidiaries of conglomerates, professionalizing small family-owned businesses by bringing in expertise from the deal partners, and improving process efficiency through productivity initiatives (better supplier contracts, overhead reductions, better working capital and CAPEX management). 
Overall, the picture that emerges from our analysis is that top, mature PE houses create value for portfolio companies on average through turnarounds which improve their margins substantially and in a sustainable manner. Such turnarounds require expertise in operational engineering and the return to such expertise may explain the persistent returns generated by these funds for their investors (Kaplan and Schoar, 2005). Could it be that what we are calling "turnaround" is simply reversion of acquired deals to the mean? The answer is no. Although the sample size of deals with more than 2 years of available data pre-acquisition is small, there is evidence against the mean-reversion argument. According to our data, mature PE houses do not seem to pick companies that were in the recent past exposed to an idiosyncratic shock, which in better times would revert to the mean and be sold with an upside. ${ }^{6}$ Finally, could it be that we simply had deals from the funds we sampled which were cherry-picked by the PE houses? This is also not the case. While we have a bias for funds of top PE houses, this is by design given we wish to understand drivers of their persistent outperformance. However, within the funds we sampled for our deals, we find there is no statistical difference between a fund's IRR and that of a pseudo fund constructed from deals we sampled from that fund.

In Section 2, we review the related literature. In Section 3, we provide a description of the data we collected and some summary statistics. In Section 4, we describe the methodology for calculating alpha. In Section 5, we discuss operating performance. In Section 6, we link alpha and operating performance. Section 7 presents the results on active ownership and governance based on interview-based data. Section 8 concludes.

\section{Related literature}

\footnotetext{
${ }^{6}$ Yet, PE might still be able to identify companies which will be subject to a positive future shock. This is something we can not rule out. However, a systematic relationship between PE-ownership and future performance shocks does not seem reasonable. To financially exploit individual shocks on a company, a PE house must have a systematic informational advantage in forecasting the future in comparison to the seller and other bidding PE houses. This systematic informational advantage appears questionable in a competitive buyout market, such as that for the large sized firms in the UK.
} 
Jensen (1989) argued that LBOs create value in their portfolio companies through a combination of high financial leverage and powerful incentive schemes. The increased management ownership provides strong incentives for managers to improve operating performance and generate cash flows. The high debt level limits manager's ability to squander free cash on wasteful investments. In addition, PE funds' active participation in the management of the companies improves monitoring.

Kaplan (1989) analyzes the post-buyout operating performance of 48 large management buyouts (MBO) of public companies completed between 1980 and 1986. Consistent with Jensen's hypothesis, he finds that in the three years after the buyout, these companies experienced increases in operating income, decreases in capital expenditures, and increases in net cash flow. Specifically, operating income, adjusted for industry changes, remained unchanged in the first two post-buyout years but increased by $24 \%$ in the third year. The median industry-adjusted net cash flow in the first three post-buyout years was $22 \%$, 43\%, and $81 \%$ larger than in the last pre-buyout year. The increases in net cash flow were driven both by increases in operating incomes and by decreases in capital expenditures. Consistent with the results on operating changes, Kaplan also finds that the mean (median) increase in market value adjusted for market-wide returns is $96 \%$ (77\%) from two months before the buyout announcement to the post-buyout sale, suggesting increases in operating performance as an important source of the buyout premium.

In her sample of 58 MBOs between 1977 and 1986, Smith (1990) also finds that operating cash flows both per employee and per dollar of book value of assets increased on average after an MBO due to better working capital management. She finds little evidence that the post-buyout cash-flow improvements are driven by cutbacks in discretionary expenses. The increases in operating cash flows were correlated with the buyout-induced changes in debt ratios and management ownership, suggesting that these organizational changes play an important role in value creation in LBOs. Lichtenberg and Siegel (1990) examine post-buyout changes using plant-level data for approximately 1000 LBOs between 1981 and 1986. They find that, for LBOs during 1983-1986, plant productivity increased from 
$2 \%$ above industry mean in the three pre-buyout years to $8 \%$ above industry mean in the three post-buyout years ${ }^{7}$. Moreover, the authors show that this enhancement in economic performance is not attributed to reductions in $R \& D$, wages, or capital investment.

The topic of measuring fund-level PE performance has received quite a lot of attention recently. The seminal paper in this area is Kaplan and Schoar (2005). Based on a sample of 746 funds raised between 1985 and 2001, the study finds that the return of private equity is close to that of the S\&P 500, net of fees ${ }^{8}$. One of the most interesting and discussed facts that has come out of this literature is that PE performance is persistent. Kaplan and Schoar find that GPs whose funds outperform the industry in one fund are likely to outperform the industry in the next and vice versa. In addition, Kaplan and Schoar find that larger funds and funds with higher sequence numbers generate significantly higher returns, suggesting that the size and the maturity of the GP matters for performance. This evidence is suggestive that mature GPs generate such value (even net of fees) through active ownership and governance, though convincing evidence in support of this has been elusive, perhaps due to lack of detailed deal-level data on their involvement with portfolio firms. ${ }^{9}$

The most recent wave of PE transactions (2001-2006) has, however, prompted researchers to re-examine whether buyouts are still creating value in this new era. Guo, Hotchkiss, Song (2007) try to answer this question with a sample of 89 US public to private transactions between 1990 and 2006. They find that gains in operating performance are either

\footnotetext{
${ }^{7}$ However, 1981 and 1982 buyouts did not experience significant productivity changes. Note that Kaplan (1989), Smith (1990), and Lichtenberg and Siegel (1990) also investigate whether LBOs improved operating performance at the expense of workers. They find that the wealth gains from LBOs were not a result of significant employee layoffs or wage reductions (see Palepu (1993) for a detailed survey of these papers).

${ }^{8}$ Benchmark to S\&P 500 implicitly assumes that beta of LBO funds is one. Jones and Rhodes-Kropf (2004) find that beta of LBO funds is 0.65 , an issue that we revisit in our robustness checks. Phalippou and Gottschalg (2007) contend that Kaplan and Schoar's results are perhaps still overly optimistic. After correcting for sample bias and adjusting for overstated accounting values, they find that PE funds under perform 3\% per year with respect to the S\&P 500. Some other studies argue that private equity as an asset class has generated unimpressive returns (net of fees) for their investors (Phalippou, 2007).

${ }_{9}^{9}$ An interesting question is whether the value enhancements are sustained after PE houses re-sell their investments. Cao and Lerner (2006) answer this question by studying the long-run performance of 526 reverse LBOs, which are initial public offerings of firms that had previously been bought out by PE funds. The study finds that, in the five years after they are re-sold, LBO firms outperform the market by approximately $0.5 \%$ per month on a risk-adjusted basis, suggesting that the value enhancements were sustained.
} 
comparable to or exceed (by $2 \%$ with some measures) those observed for benchmark firms. Leslie and Oyer (2008) find weak, in fact, generally no evidence of greater profitability or operating efficiency of LBOs between 1996 and 2004, relative to public companies.

Finally, Lerner, Sorensen and Stromberg (2008) provide evidence that in contrast to the often-cited claim that private equity has short-term incentives, buyout deals in fact lead to significant increases in long-term innovation. They find that patents applied for by firms in private equity transactions are more cited (a proxy for economic importance), show no significant shifts in the fundamental nature of the research, and are more concentrated in the most important and prominent areas of companies' innovative portfolios. The last finding is consistent with our conjecture that the substantial improvement in margins and efficiency in our sample of deals arises from a shift in focus from inefficient units to productive ones.

Evidence on buyouts in the UK: Several studies have examined PE investment in the UK, which has also experienced a tremendous increase in buyout activities in recent years. Nikoskelainen and Wright (2005) study 321 exited buyouts in the UK in the period 1995 to 2004. On average, these deals generated a $22 \%$ return to enterprise value and $71 \%$ return to equity, after adjusting for market return. They also find that operating improvements are related to organic changes rather than to divestments of assets or acquisitions. In a related paper, Renneboog, Simons, and Wright (2007) examine the magnitude and the sources of the expected shareholder gains in UK public to private transactions from 1997 to 2003. They find that pre-transaction shareholders receive a premium of $40 \%$ and that the main sources of the shareholder wealth gains are undervaluation of the pre-transaction target firm, increased interest tax shields, and incentive realignment. Harris, Siegel, and Wright (2005) study the productivity of management buyouts (MBO) plants in the UK. On average, plants involved in MBOs were $2 \%$ less productive than other plants in the same industry before experiencing a buyout. However, MBO plants experienced a substantial increase in productivity after an MBO (71 - $90 \%)$. These productivity gains are substantially higher than those reported in the US by Lichtenberg and Siegel (1990). 
Overall, the literature suggests that buyouts do create value through operating improvements, in both US and UK markets, during both the recent and the 1980 buyout booms. Our contributions to this literature lie in providing alpha - a deal-level measure of value creation or abnormal performance, showing the critical role of EBITDA margin and multiple improvements in explaining the variation in alpha, and crucially, relating alpha and operating performance to the involvement of PE in portfolio companies through interviews with GPs. ${ }^{10}$

\section{Data and sample selection}

The sample represents relatively large UK deals, all greater than $€ 100$ million in enterprise value, acquired by twelve large and mature PE houses between 1996 and 2004. We required the deals be large in order to balance the intensity of data collection effort with the overall proportion of total value of PE companies in the UK. The data-set comprises 66 deals, of which 60 were exited during 2000 to 2007. Out of the 60 exited deals, there were 4 bankruptcies. ${ }^{11}$ For each deal, we have the exact structure of cash inflows and outflows from the standpoint of the PE house involved in the deal, detailed data on financial and operating performance, and ownership and board structure. We do not have all enterprise level cash flows, which would include for example also interest and principal paid on debt. ${ }^{12}$ Softer information on governance and operational changes brought about by the PE house was collected via interviews with one of the general partners (GP) from the PE house involved in the deal, each of which lasted for 45-60 minutes. We describe the interview-based data fields later in the paper.

\footnotetext{
${ }^{10}$ Our paper is silent about the conflicts of interest between private equity houses and their investors. Axelson et al. (2007), Ljunqvist et al. (2007) and Metrick and Yasuda (2007) provide a good coverage of theoretical as well as empirical issues on this front.

${ }^{11}$ The proportion of bankruptcies -4 out of 60 - is typical of buyout data. Kaplan and Stromberg (2008) report an average of 6\% of bankrupt deals in a large sample of buyouts since 1980 .

${ }_{12}$ We also do not have all cash flows for the 6 un-exited deals because there is not any exit cash flow from sale nor can it be deemed to be zero as in the case of bankruptcies. Therefore, the end enterprisevalue cash flow was simulated using the EV / EBITDA multiple at the start of the deal and applying that to 2006 year-end EBITDA. Our results are robust to alternative and more conservative assumptions on these un-exited deals, including one assumption that they produced no terminal cash
} 
Table 1, Panel A shows that our deals are well spread-out over time (within our sample period) although there is some concentration in 1999-2000 and 2002-2003 in terms of acquisitions and in 2004-2006 in terms of exits. The fall in deal number and flow during 2001 is due to the global recession and tightening of credit.

Table 1, Panel B provides additional summary statistics for the deals. Deals in our sample have high mean IRR (35.5\%) and cash multiples (2.8), with significant outliers on either side. While a high value for average IRR is to be expected from a sample of deals from mature PE houses (Kaplan and Schoar, 2005), this does beg the question of how representative our sample is of the overall PE universe in the UK, and even within the funds of PE houses we focus on. We discuss this sample selection issue in greater detail below. The mean entry EV/EBITDA multiple is 9.0 whereas the corresponding exit multiple is 10.9, already indicating that on average our deals seem to have improved their market valuations (consistent with the findings of Kaplan, 1989). The median debt to equity ratio at entry is 1.6 (debt to enterprise value of 60\%). This is somewhat smaller than the usual LBO capital structure believed to be $70 \%$ debt and $30 \%$ equity (Axelson et al., 2008). The median debt to equity ratio at exit is 0.6. Since the debt to EBITDA ratio does not fall as much (it goes from median entry value of 5.1 to exit value of 4.0 ), it appears that while the debt to equity ratio falls for PE deals during their life partly due to improvements in coverage ratio (Debt/EBITDA), it does so mainly due to improvements in equity value over deal life.

Coming to the sample-selection issue, Table 2 provides several relevant comparisons between our sample and the universe. First, Panel A shows that on the one hand, the number of deals in our sample is significantly smaller than that of all UK deals over the sample period. However, since we focus on large deals, we cover a higher percentage of deals by volume. In particular, the enterprise value range below $€ 100 \mathrm{mln}$, which we exclude, constitutes only $18 \%$ of the universe in value terms. On the other hand, the other two ranges - €100mln to €500mln and greater than $€ 500 \mathrm{mln}$, which constitute $27 \%$ and $56 \%$ respectively

flow whatsoever. However, we have verified that such a pessimistic scenario is unlikely to be appropriate for these deals. 
of the universe (again, in value terms), constitute $16 \%$ and $84 \%$ of our sample. Ultimately, because we are studying the performance of large, mature PE houses, we have a sample with a large-size bias. In terms of representation of deals larger than €100mln, we have about $30 \%$ of this sub-sample. $^{13}$

Second, and more importantly, Panel B presents the comparison of deal performance in terms of IRR to that of the universe and its relevant parts. Here, we first need to convert our gross deal-level IRRs (before fees charged by PE houses to fund investors) to net IRRs (after fees, or in other words, IRRs from the viewpoint of fund investors). This is because the data we have on the overall universe is primarily in the form of net IRRs. To this end, we construct an artificial fund of our sample deals and calculate its IRR. The pseudo-fund starts in year 1996 and lasts for 12 years until year 2007; investments or cash inflows take place in years 1-9 (with small investments in years 10 and 11 as well); the bulk of the investments occur in years 3-9; cash payouts start in year 5 and in the last 3 years, the fund only has cash payouts. Using this pattern of cash inflows and outflows, we calculate the gross IRR of the pseudo-fund. Next, we take out from the gross IRR a $2 \%$ annual fee and $20 \%$ carry for IRR above (the typical) benchmark (the market return of $8 \%$ ). ${ }^{14}$ This pooled net IRR for our deals is $25.8 \%$, which is close to the simple average net deal IRR of $26.9 \%{ }^{15}$

If we focus only on the returns of the 28 specific funds from which our deals were financed, we get a simple average of net fund IRRs of $26.0 \%$ and a median of $24.0 \%$. The difference between the fund IRR and the average IRR of our deals per fund is in fact not statistically significant. This illustrates that we have in terms of performance, a good representation of deals within the funds we sampled.

\footnotetext{
${ }^{13}$ It should be noted though that the large-size bias makes our sample more comparable to the benchmark group we employ, which consists of publicly quoted peers, the size of which is generally larger than a typical private equity deal in the entire universe of such deals.

${ }^{14}$ More specifically, if a) Gross IRR $<=10 \%$, then LPs keep all return except $2 \%$ fees, so that Net IRR $=$ Gross IRR - 2\% fees; b) $10 \%<$ Gross IRR $<12.5 \%$, then LPs keep all return up to $10 \%$ except for $2 \%$ fees and GPs keep all return from $10 \%$ to $12.5 \%$, so that Net IRR = Gross IRR - $2 \%$ fees - (Gross IRR $-10 \%)=8 \%$; and c) Gross IRR $>=12.5 \%$, then LPs and GPs share in 80:20 ratio the return exceeding $12.5 \%$, so that Net IRR $=$ Gross IRR $-2 \%$ fees $-2.5 \%-20 \% *$ (Gross IRR $-12.5 \%)$.

${ }^{15}$ The return of the pseudo fund based on "public market equivalent (PME)" (based on Kaplan and Schoar, 2005) relative to the sector is $78.6 \%$ and relative to FTSE250 is $164.5 \%$. We explain in the next section our exact computation of PME.
} 
Also the sampled funds are a good representation of similar-sized funds, once we take into account the fact that we are focusing on funds whose sizes are above $€ 500$ million. All 113 UK funds with the same vintage year 1994-2003 as our sample have a simple average net IRR of 18.3\% (based on Thomson Financial Venture Expert figures). Yet large funds have a higher return. Specifically, the 44 funds with a size above $€ 500$ million as the participating funds in our sample show a net IRR of $25.3 \%$, which is again not statistically significantly different from the $26.0 \%$ net IRR average of our 28 participating funds.

\section{Alpha, a measure of abnormal financial performance}

\subsection{Methodology}

The key question we want to answer in this study is how much of the excess return generated by PE firms, relative to quoted peers, comes from pure financial leverage, and how much of it comes from genuine operational improvements. To disentangle the effect of leverage from that of operational improvements, we first calculate the IRR of the deal - its levered return - using the entire time pattern of cash inflows and outflows for the deal, as experienced by the PE house (before fees), and then we un-lever this IRR. Next, we benchmark this un-levered return to (similarly calculated) un-levered return for the quoted peers of the deal. The residual un-levered return is what we call the "alpha" of the deal.

Formally, to un-lever the levered return of deal $i, R_{L, i}$, we use the un-levering formula:

$$
R_{U, i}=\frac{R_{L, i}+R_{D, i}\left(D / E_{i}\right)}{\left(1+D / E_{i}\right)}
$$

The un-levered IRR, $R_{U, i}$, corresponds to the return generated at the enterprise level. Since $R_{D, i}$ for each deal is not available, we assume that $R_{D, i}=5 \%$ for all deals, which is our estimate of the average level of cost of debt in the market during our sample period. While the cost of debt for all companies in our sample is unlikely to be $5 \%$, we verify later the robustness of our results to varying $R_{D, i}$ from $2.5 \%$ up to $7.5 \%$. Note that higher values of $R_{D, i}$ result in greater un-levered return for the same levered return, generating greater abnormal performance for the deal. The leverage ratio $D / E_{i}$ of the deal is the average of the entry and 
exit debt to equity ratio of the deal. Since the starting $D / E$ is higher than exit $D / E$ for most deals, the average pattern of leverage is one of decline over the life of the deal. Hence, we employ the average of the two. Finally, the un-levering formula (1) assumes that tax shields are as risky as profits of the firm. Given the high leverage of PE deals, this appears a reasonable assumption.

We also apply (1) to un-lever sector IRRs. In this case, a sector is defined as containing all quoted European "peer" companies sharing the deal's 3-digit ICB code in Datastream. In particular, we calculate over the life of each deal the equally weighted average of the annualized total return to shareholders (TRS) of these quoted peers of the deal, denoted as $R_{S, i}$. The weighted average of returns of these peers represents the benchmark levered sector return, which we un-lever using (1), with the $D / E$ for the sector being taken as the average over the period 1996-2007. As we work with all cash flows and operational numbers in $€$, we convert all $£$ figures into $€$ at the exchange rate applicable in that year.

After obtaining the un-levered returns, $R_{U, i}$, and $R_{S U, i}$, which are purged of the effect of financial leverage, the next key step is to measure the portion of PE excess return that is brought about by genuine operational improvements. We employ for this purpose a one factor model and express the un-levered return of each firm in terms of the contemporaneous unlevered sector return as follows:

$$
R_{U, i}=\alpha+\beta_{S} R_{S U, i}+\varepsilon_{i}
$$

Though in most of our analysis, we assume that $\beta_{S}=1$ rather than estimating it, we describe our methodology more broadly and examine the implications of estimated $\beta_{S}$ in our robustness checks. ${ }^{16}$ In particular, since we have only one IRR value for each deal, $\alpha$ and $\beta_{S}$ can be estimated only in the cross-section. In other words, the regression model corresponding to (2) implicitly needs to assume that each deal in our sample is a random draw from the PE universe which has identical but independently distributed portfolio companies 
with $\alpha$ and $\beta_{S}$ characteristics. $\beta_{S}$ is a measure of correlation - the "beta" - between PE return and the quoted public sector return. The intercept, $\alpha$, captures the component of PE return that is not linked to industry-wide risks, and therefore can be considered an estimate of average excess return on the deal. The residual, $\varepsilon_{i}$, measures the idiosyncratic under-/outperformance of each individual private equity deal relative to average PE abnormal performance of $\alpha$ and has a mean of zero.

In essence, applying (1) and (2) allows us to make the following decomposition or performance attribution of each deal IRR:

(i) Deal-level "alpha” or abnormal performance: $\quad \alpha_{i}+\varepsilon_{i}$

(ii) Unlevered sector performance: $\quad \beta_{S} R_{S U, i}$

(ii) Total leverage effect: $\quad R_{L, i}-R_{U, i}$

The leverage effect $\left(R_{L, i}-R_{U, i}\right)$ measures the total effect of leverage on deal return. More often, however, we are interested in measuring the effect of the additional leverage firms take on after they are purchased by PE. To get at the incremental effect of increased leverage, we re-write (2) in terms of $R_{L, i}$ as follows, where $D / E_{i}$ and $D / E_{S, i}$ denote the deal and sector debt to equity ratios respectively:

$$
R_{L, i}=R_{U, i}\left(1+D / E_{i}\right)-R_{D, i}\left(D / E_{i}\right)
$$

whereby

$$
\begin{aligned}
R_{L, i} & =\alpha_{i}\left(1+D / E_{i}\right)+\beta_{S} R_{S U, i}\left(1+D / E_{i}\right)+\varepsilon_{i}\left(1+D / E_{i}\right)-R_{D, i}\left(D / E_{i}\right) \\
& =\left[\alpha_{i}+\varepsilon_{i}\right]+\left[\beta_{S} R_{S U, i}\left(1+D / E_{S, i}\right)-R_{D, i}\left(D / E_{S, i}\right)\right]+\left[\left(\beta_{S} R_{S U, i}-R_{D, i}\right)\left(D / E_{i}-D / E_{S, i}\right)+\left(\alpha_{i}+\varepsilon_{i}\right)\left(D / E_{i}\right)\right]
\end{aligned}
$$

This equation provides an alternative decomposition of each deal IRR:

(i) Deal-level "alpha" or abnormal performance: $\alpha_{i}+\varepsilon_{i}$ measures the excess asset return generated at the enterprise level of the portfolio company for PE investors, and it is purged of the effect of leverage financing the firm takes on.

\footnotetext{
${ }^{16}$ Note that (2) employs total returns rather than returns in excess of the risk-free rate. This does not affect results when beta is assumed to be one. When beta is different from one, the assumption is not
} 
(ii) Levered sector return: $\beta_{S} R_{S U, i}\left(1+D / E_{S, i}\right)-R_{D, i}\left(D / E_{S, i}\right)$ measures the effect of contemporaneous sector returns, including the effect of sector-level leverages

(iii) Return from incremental leverage:

$\left(\beta_{S} R_{S U, i}-R_{D, i}\right)\left(D / E_{i}-D / E_{S, i}\right)+\left(\alpha_{i}+\varepsilon_{i}\right)\left(D / E_{i}\right)$ captures the amplification effect that

a) the incremental deal leverage beyond the sector leverage, $\left(D / E_{i}-D / E_{S, i}\right)$, has on the sector returns and b) the total leverage has on enterprise-level abnormal performance.

The purpose of performing such a decomposition or return attribution is three-fold. First, it is to see if the sample deals from mature PE houses generated a significantly positive average alpha or not. Second, if we believe that alpha is the abnormal performance attributable to operating strategies and changes attempted by the PE houses, then what is the cross-sectional distribution of this abnormal performance? And, third and perhaps most importantly, is there evidence at the individual deal level that alpha is related to actual measures of operational improvements and to the nature of engagement by PE houses?

Before we proceed to discussing our results, it is useful to note some of the limitations of our methodology. First, it treats leverage as purely financial gearing rather than having some incentive effect. Second, our methodology is subject to the usual problems associated with IRRs, that they are a way of discussing cash flows rather than being actual realized returns and that they translate into returns only under extreme assumptions of constant and common discount rates and reinvestment rates. On the second issue, another approach we adopted was to calculate a public market equivalent (PME) for each deal. We used as benchmark the market (FTSE250) or sector return to discount all cash flows and then calculate the ratio of discounted cash flows to the largest cash inflow for the deal (in the spirit of Kaplan and Schoar 2005). We discuss the relationship between alpha, IRR and PME in the next section. Finally, note that since we do not have the exact cash payouts on debt, we are unable to employ the methodology of Kaplan (1989), which is to simulate the enterprise-level (not equity) cash flows that would be obtained by investing these cash inflows in the quoted 
sector and examining the cash outflows thus generated. We chose to use IRR given its simplicity and also that of its decomposition into alpha and related components.

\subsection{Average alpha and its characteristics}

Table 3 summarizes the results from employing the decomposition method of Section 4.1. It presents seven panels: (1) overall sample of 66 UK deals; (2) the sample of 60 deals which excludes the 6 un-exited deals; (3) the set of 15 deals where the sector generated negative returns during PE ownership; and, (4) - (7) report how sensitive our results are to variations in benchmark assumptions.

(1) We find that out of the average IRR of $35.5 \%$ for all 66 deals, sector risk and leverage amplification on it account for a total of $11.1 \%$. That is, less than one third of the total return is attributable to sector-picking ability of PE houses or simply to pure luck. The average alpha of $8.9 \%$ is statistically significant (significant at a $1 \%$ level), confirming that large, mature PE houses do generate higher (enterprise-level) returns compared to benchmarks and not all of these returns are attributable to sector exposure and financial gearing. The medians tell a similar story. Interestingly, since quoted sectors have little leverage on average (just $20 \% \mathrm{D} / E$ ratio), most of the incremental leverage effect (14.3\% out of $15.5 \%$ ) is due to deal leverage, above and beyond the sector.

(2) When we only include deals in the analysis that were exited by 2008, the results do not vary much - our exit simulation for the 6 un-exited deals is conservative and has nearly no impact on the average level of alpha. In fact, the alpha estimate is hardly affected when we include deals with simulated exits. Hence we keep the un-exited deals in our data set for the following analyses.

(3) Another way of assessing the systematic risk of PE deals is to examine their performance during sector downturns. While the flow of capital into PE funds is clearly cyclical (Kaplan and Stein, 1993; Acharya, Franks and Servaes, 2007; Kaplan and Stromberg, 2008), this does not necessarily imply that the performance of PE companies is also cyclical. When we examine the set of 15 deals for which the quoted peers had a negative total return to shareholders over deal life, the results are striking. Since sectors are under-performing for 
these deals, their contribution to deal returns is in fact negative. The alpha for these 15 deals is $17.7 \%$ on average, almost twice the alpha for the overall sample in section (1). The alpha itself almost wipes out the negative return contributed by the sector (including deal leverage amplification of the sector's negative return). In other words, PE deals in sectors affected by downturns do even better than PE deals on average.

This is consistent with the perceived wisdom that PE deals tend to involve firms that have stable cash flows relative to their peers and thus most likely lower systematic risk than the quoted peers. Overall, this evidence suggests that our alpha estimates based on a beta of one on sector is at best a conservative estimate of actual deal-level abnormal performance. ${ }^{17}$

Table 3, Panels (4) - (6) illustrate that these conclusions are robust to variations in the assumptions on $R_{D, i}(7.5 \%$ or $2.5 \%)$ or $D / E_{i}$ (leverage at acquisition rather than average leverage during PE ownership). Under each scenario, alpha stays between $8.0-10.0 \%$ and statistically significant.

Panel (7) shows that this is also true for an alternative (lower) assumption on $\beta_{s}$, the systematic risk of the deals. In particular, we ran the cross-sectional regression of equation (2) linking un-levered deal returns to un-levered sector returns, and estimating $\alpha$ and $\beta$ of this relationship. The estimated coefficients are $\alpha=14.0 \%$ (t-stat of 3.94) and $\beta=0.44$ (t-stat of 2.62). This suggests that based on un-levered returns, the deals do appear to have less systematic risk than un-levered sector returns. Also, the estimate of alpha is larger than that obtained in Panel (1) which assumed $\beta=1$. Since almost all our results (Table 4 onwards) are qualitatively robust to these changes, we employ the case $\beta=1$ for rest of the paper.

In Table 3, Panels B and C we compare alpha and the alternative financial performance measures IRR, PME of the deals relative to the sector, and the deals' PME

\footnotetext{
${ }^{17}$ When we examine the operating performance of these 15 deals, for almost all measures, these deals fare superior compared to their sectors and to the overall PE deal sample: these deals tend to grow their revenues as well as earnings faster and at better margins, have lower employment growth than the sector but are much more profitable per employee, and cut CAPEX, SGA and Fixed Assets when measured relative to Sales (but they do not grow their EBITDA multiple more than other deals). This suggests pursuit of efficient growth at PE companies which enables them to withstand sector downturns better than their quoted peers; in fact, these deals seem to thrive on such downturns in terms of outperformance relative to quoted peers.
} 
relative to the market (FTSE250). We find that $I R R=23.0 \%+1.4 *$ alpha. Thus, IRR and alpha are positively related $(t=5.11)$ but the association is far from perfect as revealed by the $R^{2}$ of $52 \%$. Consistent with the positive alpha, $\mathrm{PE}$ also generates on average returns above the sector and the market: average sector PME is 106.0\% and average FTSE250 PME is $173.2 \%{ }^{18}$ Overall the evidence points to out-performance of PE deals in our sample in a manner that is robust to alternative measures or peer groups, as the large, positive correlations between all four performance measures (Panel C) indicate.

\subsection{Alpha and deal types}

Table 4, Panel A reports the sample breakdown by 8 different deal types for all 66 deals and shows how alpha, IRR and PME differ across those. It should be noted, however, that given our overall sample size, these finer partitions are even smaller in terms of sample size (in fact, differences across partitions are seldom significant).

(1) Alpha is substantially higher at $14.3 \%$ for club deals (25 in all) that involve more than one private equity house, compared to $5.7 \%$ for non-club deals (41 in all).

(2) There seems to be no monotone relationship between alpha and size, with medium-sized deals in the range of $€ 500 \mathrm{mln}-€ 1$ bln generating on average a higher alpha (11.1\%) compared to the deals with size below $€ 500 \mathrm{mln}$ (8.3\%) and above $€ 1 \mathrm{bln}$ (8.4\%).

(3) Unlike the PE sector in the US, public to private transactions in the UK have been relatively fewer and only half of our sample comprises public company transactions (of which 23 transactions involve subsidiaries of public companies). Public carve-outs have the highest alpha of 14.5\%; secondaries acquired from other PE houses being next with an alpha of 10.3\%; and the public-to-private transactions being the worst with an alpha of zero. The alpha being lower for public to private transactions of whole companies suggests that their high IRRs are primarily due to sector-picking or luck, and its amplification due to financial leverage.

\footnotetext{
${ }^{18}$ We also obtain that IRR $=5.0 \%+0.18 *$ PME FTSE250 $\left(t=4.13 ; \mathrm{R}^{2}=54 \%\right)$ and IRR $=16.9 \%+0.17 *$ PME sector $\left(\mathrm{t}=2.67 ; \mathrm{R}^{2}=39 \%\right)$.
} 
(4) In terms of exit type, sale to another corporate ("trade sale"), sale to another private equity house ("secondary") and IPOs constitute the bulk of the exits. Alpha is the highest for trade sales (16.2\%), followed by IPOs (12.4\%) and secondaries (9.1\%). The four bankruptcies have an average alpha of $-30.7 \%$ and play a significant role in lowering the overall sample alpha.

(5) As a first step towards unraveling the operating strategies at work in PE deals, Table 4, Panel A shows alphas also for “organic” deals - that is, deals without any significant acquisition or divestment activity, and "inorganic" deals - the deals with acquisitions ("rollups”) and deals with divestments. 36 of our 66 deals are organic in this respect, 17 are rollups and 13 have divestments. Overall, in terms of both IRR and alpha, the organic deals perform better; they have an average (median) IRR of 48.5\% (40.3\%) and average (median) alpha of $15.8 \%(14.3 \%)$. Divestment deals fare the worst; they have low IRR as well as negative alphas. The roll-ups, in contrast, have an impressive average IRR of $28.6 \%$ but the average alpha is just $3.4 \%$, signifying that it is important to correct for sector-wide and leverage effects while measuring PE abnormal performance.

One possible explanation for the difference between organic and inorganic deals is that acquisition and divestment deals take longer than other deals; in our sample, these deals take 4.53 years (54 months) on average, compared to the overall mean duration of 3.84 years (46 months) and mean duration of 3.3 years (40 months) for organic deals. The longer duration would penalize the performance of inorganic deals since we focus on IRRs as a measure of performance. This is reflected in the fact that the PME based on comparable sectors is 123.0 for acquisition deals and in fact nearly equal to PME of 124.5 for the organic deals. Divestment deals, in contrast, appear to perform the worst on all accounts and thus the duration argument does not help explain their relatively poor performance. Their poor performance might be due to the fact that asset sales are perhaps symptomatic of weak deals.

(6)-(8) In contrast to the common argument that high leverage works as a performance stimulus, we do not find a clear positive relation between high leverage (measured in quartiles) and alpha. Also, a privileged relation to the seller, instead of a 
competitive auction, does not result in a higher alpha. Finally, when we examine deals by entry date, alpha appears to be the highest for acquisitions made in 2001-02, reflecting depressed market valuations in that period.

\section{Operating performance}

\subsection{Operating measures}

The next step in our analysis is to see if alpha is related to operating abnormal performance at the enterprise level. Operating abnormal performance is reflected either in a larger increase in EBITDA of the portfolio company during PE ownership or in a larger increase in the EBITDA after PE ownership. To disentangle the PE impact on EBITDA during PE ownership, we focus on a) profitability (margin=EBITDA/sales) and b) sales. We capture the impact on the company after the PE ownership period by analyzing c) the EBITDA multiple (enterprise value/EBITDA). We have to rely here on the assumption that market expectations are rational at exit, since we do not have operational figures after the PE phase for many of the deals (trade sales for example).

The three measures we analyze are in detail:

a) EBITDA (Earnings before Interest, Taxes, Depreciation and Amortization), equal to Operating revenues - COGS (cost of goods sold) - SG\&A (selling, general and administrative expenses) - Other (e.g., R\&D) = Operating income [+ Non-operating income].

Academics and practitioners widely use EBITDA since it shows a company's fundamental operational earnings potential. EBITDA is, in contrast to 'Net Income', not distorted by (1) expenses outside of a company's business (interest and taxes) and (2) non-cash charges due to allocation of historical cost of an asset (depreciation and amortization). Also EBITDA, in contrast to 'Operating Cash Flow', does not include changes in working capital and capital expenditure, which are altered by changes in liquidity or capital investment decisions. However, EBITDA is not a defined measure according to Generally Accepted Accounting Principles (GAAP) or IFRS/IAS. In the present paper we define EBITDA excluding 'Non- 
operating income'. ${ }^{19}$ Often this measure is more precisely referred to as EBITDAE (Earnings Before Interest, Taxes, Depreciation, Amortization and Exceptionals).

b) Sales, equal to operating revenues earned in the course of ordinary operating activities.

c) Enterprise value to EBITDA multiple. In our data, enterprise values are available only at acquisition and at exit. For these dates, the PE house also reported the total debt and total equity of the company. For the 4 bankrupt deals, the equity value is assumed to be 0 at the time of bankruptcy (exit).

To identify the PE impact on performance changes between pre-acquisition and during PE ownership, it is crucial to have access to a consistent dataset for both periods. Probably the only data source without a structural inconsistency is the data PE houses collect themselves in the due diligence process and through monitoring efforts during their ownership. ${ }^{20}$ This is the data we use in the present paper.

\subsection{Operating performance pre-acquisition}

Table 5, Panel A provides a snapshot of the pre-acquisition operating performance for the deals in our sample (available on average for about 2 years pre-acquisition) and each corresponding sector. ${ }^{21}$ PE-owned companies are clearly not a random selection from the sector in terms of pre-acquisition operating measures. On average the targeted companies are statistically significantly smaller in sales, EBITDA, enterprise value, and number of employees. Interestingly, targeted companies show a statistically significant higher

\footnotetext{
${ }^{19}$ The reason for the exclusion of 'Non-operating income' is that this measure contains income derived from a source other than a company's regular activities and is by definition nonrecurring. For example, a company may record as non-operating income the profit gained from the sale of an asset other than inventory (which can be large in relation to the operating income). From a practitioner's perspective, a EBITDA multiple including 'Non-operating income', would not be a helpful measure to understand the price paid in relation to the current performance capability. From our perspective, the operational performance indicator EBITDA would then be subject to a measurement error.

${ }^{20}$ There are mainly two reasons why consistent data is difficult to obtain. First, with exception of the publicly available returns of PE funds (e.g., at the California Pension Fund website), PE-owned companies are not subject to public disclosure of financial data and are largely exempt from such requirements. Second, even with a database like 'UK company house', which provides accounting measures on private companies, pre-acquisition data for parts of companies, which are necessary to estimate the impact of 'carve-out' deals (only part of a company is sold), are mainly unavailable.

${ }^{21}$ To determine precisely whether in entry or exit year PE-ownership was in place long enough to influence a company's performance, we count a year as PE-ownership year only if the fiscal year end is at least 6 months after the entry and not at least 6 months after the exit.
} 
profitability, which might be explained by the inverse relationship between sales size and profitability generally found in corporate finance data.

Table 5, Panel B shows the growth in pre-acquisition operating performance from year -2 to the last year before acquisition. Targeted companies show a robust increase in nominal sales but a constant profitability. Importantly, in terms of performance trends, PE owned companies do not differ statistically significantly from their sector peers in the preacquisition phase. Although the sample size is small for deals with more than 2 years of available data pre-acquisition, overall there is evidence against a simple mean-reversion argument that PE targets recent under-performers. According to our data, PE does not seem to pick companies that were in the recent past exposed to an idiosyncratic shock, which in better times would revert to the mean and the target potentially be sold with an upside. Accordingly, the exogeneity assumption of the PE acquisition, which is fundamental for any identification of a causal PE impact in our analysis to follow, does not seem to be violated.

\subsection{PE impact on operating performance}

Table 6 reports for each operating measure $y$ : (1) the cross sectional average of the difference $\Delta y_{i}=\bar{y}_{i, \text { durPE }}-\bar{y}_{i, \text { prePE }}$, where $\bar{y}_{i}$ denotes the average of measure $y$ for deal $i$ during pre-acquisition (prePE) or PE-ownership period (durPE), and (2) comparison of this difference to that for the corresponding sector $\Delta y_{s}=\bar{y}_{s, \text { durPE }}-\bar{y}_{s, \text { prePE }}$. To be precise, $\bar{y}_{i, p r e P E}$ is the average of variable $y$ based on all data available for deal $i$ in the pre-acquisition period (e.g., the average of the variable in $t=-2, t=-1$ and $t=0$, where $t=0$ denotes the acquisition year). Similarly, $\bar{y}_{i, \text { durPE }}$ is the corresponding average based on all data available during the PE-ownership period (e.g., the average of the variable in $t=1, t=2$ and $t=3$ if the deal lasted for three years). The table also reports these statistics for organic deals and inorganic deals separately, since the balance sheet numbers might get artificially inflated or deflated in the presence of acquisition and divestment activities. The results are as follows: 
(1) The difference in log of nominal sales between pre-acquisition and PE ownership periods is substantial and implies a statistically significant total nominal sales growth during PE of around $20-30 \%$ (the difference in logs provide a percentage change from preacquisition to during PE average nominal sales). The difference in margin levels is $0.8 \%$, but not significant. We were somewhat surprised to find that the employment (FTE) is not shrinking much. ${ }^{22}$ While there is substantial variation in all these operating statistics across deals, they immediately seem to counter two myths about PE deals prevailing in the media: it does not seem that PE deals in our sample are asset-strippers since they show substantial growth in revenues over their life; it also does not seem that PE deals in our sample cut jobs.

(2) Relating the operating performance of deals $\left(\Delta y_{i}\right)$ to that of their quoted peers $\left(\Delta y_{s}\right)$ helps us evaluate operating abnormal performance. We test if the difference of differences $\left(\Delta y_{i}-\Delta y_{s}\right)$ is significant (last column in Table 6). ${ }^{23}$ Results show that on average, deals in the overall sample, and in particular the inorganic ones, outperformed their sector peers in terms of EBITDA multiple growth. The multiples of the inorganic deals increase by 2.9 points ( $\mathrm{t}=2.3$ ) from entry to exit. In comparison, the sector multiples stay constant with an average $\Delta y_{s}$ of -0.3 . In contrast to this result on the multiple, there is only directional evidence for outperformance in terms of expanding sales and improving margins above the sector, since the differences are not statistically significant to the sector. Results are similar when we exclude deals without acquisitions and divestments.

However, when looking at the difference in growth (or, in other words, trend) from pre-acquisition to PE-ownership phase, we find a statistically significant out-performance of margin growth differences for organic deals. Specifically, we calculate for each deal $i$ an average (annualized) growth or trend in the pre-acquisition and PE-ownership phases in order to derive a difference in growth $\left(\Delta^{2} y_{i}=\overline{\Delta y}_{i, \text { durPE }}-\overline{\Delta y}_{i, p r e P E}\right)$. For example, the trend in pre-

\footnotetext{
${ }^{22}$ In another study, Amess and Wright (2007) and Amess, Girma and Wright (2008) examine the effects of UK LBOs on wages and employment and also conclude that LBOs have an insignificant effect on employment growth.

${ }^{23}$ We use a weighted average for the sector margin and multiple, which is total EBITDA of the sector divided by total sales or total enterprise value (inverse multiple), respectively, to avoid the distortion coming from outliers in the sector, given that we have only 30-50 companies in each three digit sector.
} 
acquisition margin for deal $i$ is determined as $\overline{\Delta y}_{i, p r e P E}=\left(m \arg i n_{t=0}-m \arg i n_{t=-2}\right) * 1 / 3$. Similarly, the trend in margin during PE-ownership period is calculated as $\overline{\Delta y}_{i, d u r P E}=\left(m \arg i n_{t=3}-m \arg i n_{t=1}\right) * 1 / 3$. When comparing the trend in margin between preacquisition and PE-ownership phases, we find that organic deals have a 1.6\% higher change in margin during PE ownership than pre-acquisition. The result also stays significant when we take the sector movements into account (that is, examine the difference of differences $\Delta^{2} y_{i}-\Delta^{2} y_{s}$ ), since there is no difference in sector margin growth between the two periods $\left(\Delta^{2} y_{s}=0\right)$.

We test these effects of PE ownership on operating performance in a multivariate regression setting and in fact we find them to be present and stronger for both difference-ofdifferences - in average margin as well as growth in margin. Here, we control for additional factors, in particular the duration of the deal and if a deal went bankrupt or was not exited until 2008. As with the univariate setting, we focus on the difference in effects between PEownership period and pre-acquisition period, relative to this difference for the quoted sector. We do this in order to avoid the problem of unobservable, time-invariant deal-specific variables and unobservable, time-variant sector-specific variables, which might be correlated with the explanatory variables of interest.

In Table 7, Panel A we start with the dependent variable being the difference in average margin between the PE-ownership and pre-acquisition phases $\left(\Delta y_{i}=\bar{y}_{i, \text { durPE }}-\bar{y}_{i, \text { prePE }}\right)$. The PE impact (measured with a PE dummy) is insignificant by itself, confirming the univariate results, but always significant once we control for duration of the deals. In particular, PE ownership increases the margin level by on average 3.9\% to $4.2 \%$, and this impact stays significant even when we control for bankruptcies, un-exited deals, inorganic strategies and sales growth. Interestingly, the length of the PE ownership (duration) reduces the impact by $0.7 \%$ to $0.8 \%$ per year of holding. Our interpretation of this finding is not that PE becomes counterproductive after a while; instead we think that PE houses tend to 
stick to dogs (underperforming deals) longer and wait for better times to sell. Taking this negative duration effect into account, the average PE impact on margins for (in)organic deals is in total $1.5 \%$ to $2.1 \%$ ( $0.7 \%$ to $1.4 \%)$, given an average holding length of 3 (4) years. This is equivalent to a margin increase of roughly one-tenth from its pre-acquisition level. Surprisingly, but in line with the finding that alpha is the highest when the sector return is negative, a decreasing sector margin has a positive impact on the deal margin.

Table 7, Panel B reports the same regression as in Panel A with an exception of the dependent variable being the difference in margin growth between PE-ownership and preacquisition periods $\left(\Delta^{2} y_{i}=\overline{\Delta y}_{i, \text { durPE }}-\overline{\Delta y}_{i, p r e P E}\right)$. This specification takes into account trends that existed before PE ownership. The results further bolster the findings from Panel A. PE alters the margin growth trend by $3.0-3.2 \%$ p.a., which is reduced by $1.5 \%$ (2\%) p.a. for (in)organic deals due to the negative holding length effect. This impact is even more pronounced than that observed in Panel A, since we control for the weak negative trend before PE ownership. However, this regression requires two years of operating data preacquisition, which reduces the sample size to 38 deals. ${ }^{24}$

In Table 7, Panel C we provide the same analysis for the EBITDA multiple as we have done in Panel A for the margin. We find an effect of PE ownership when we use logs of the entry and exit EBITDA multiples: PE ownership increases the multiple from entry to exit by $42-43 \%$, which is again lowered by a negative duration effect of $7-8 \%$ per holding year. We interpret the negative holding length effect as before: PE holds dogs longer. So in total, deals increase their multiples by $10-19 \%$ based on specification (4) as the positive impact of $42-43 \%$ is lowered by the negative duration effect of 32\% (4 x 8\%) for inorganic deals and by $24 \%$ (3 x 7\%) for organic deals.

\footnotetext{
${ }^{24}$ For even a smaller sample, data on CAPEX, SGA and Fixed Assets were available. CAPEX and Fixed Assets both grow on average. SGA rises too. Perhaps more interestingly, the ratios of SGA to Sales and Fixed Assets to Sales, have a negative CAGR over deal life (by mean or by median) and CAPEX to Sales has a small positive mean and median CAGR. Taken together, these summary statistics also cautiously point toward efficient growth - an improvement in efficiency of capital usage and reduction in overheads at companies during the PE phase.
} 
We ran the same analysis for sales. But although the coefficient of the PE dummy on sales stayed throughout positive, we were not able to find a statistically significant PE effect.

\section{Alpha and operating performance}

Having separately identified financial (alpha) and operating abnormal performance of PE deals relative to quoted peers, we investigate in Table 8 the relationship between the two measures. Specifically, we regress alpha on increase in EBITDA margin, growth in sales and change in EBITDA multiple, all relative to the sector. We include duration and size of the deal as additional controls along with a dummy variable for inorganic strategy and a dummy for deals which went bankrupt.

Out of the three measures of operating performance, the two which we have identified as being causally altered by PE ownership also show up as significant determinants of alpha: Both EBITDA margin and multiple changes have a positive and economically meaningful impact on alpha. According to specification (4), 1\% growth in EBITDA margin increases alpha by $1 \%$. In addition, a growth of the multiple from entry to exit by $100 \%$ increases alpha by $10.3 \%$. The contribution of these operating performance changes is substantial in explaining alpha. In the previous section we identified an average alpha of $8.9 \%$; an average PE impact on EBITDA margin of $1.5-2.1 \%$ and on multiple of $11-19 \%$. Based on the estimated coefficients in specification (4), we are thus able to explain nearly half of the alpha.

Finally, specific deal entry points in time come up significant, when we employ dummies for the entry year of the deal, specifically for the periods 1996-2000 and 2001-02. In comparison to the base group of 19 deals with an entry in year 2003 or 2004, the deals in previous years were doing substantially better. This might correspond to availability of cheap debt financing, a phenomenon believed to be at work especially for PE deals struck during 2003 to mid-2007 and is likely responsible for the somewhat high valuation multiples paid by PE houses during 2003-07 (Acharya, Franks and Servaes, 2007; and Kaplan and Stromberg, 2008). Note that in principle this effect should be captured (at least partly) also in the multiple increase for the deal. However, note also that the significance and size of the estimates on 
margin and multiple growth relative to the sector is little affected by omitting time dummies for entry years (results are available upon request).

Another interesting possibility is that PE houses may have been lucky on some deals simply because they bought them at the right time when the margins or multiples in the sector were growing. We therefore also tried an alternative specification which separately includes the sector and deals' growth for all three operating measures, instead of using the differences between the deal and the sector growth. Again only margin and multiple improvements of the deal show up significant; operating sector trends are not generating alpha (results are available upon request).

Our findings are also robust to alternative financial performance measures. We simply replace in Table 8, specification (4) the dependent variable alpha with either a) PME based on sector, or b) PME based on market returns or c) IRR (results again available upon request). For example, with PME based on sector, margin improvement is significant $(\mathrm{t}=$ 1.68) with a coefficient of 12.1 . Hence a $1 \%$ margin increase above the sector moves the PME by roughly $10 \%$, given an average PME based on sector of 106.0. This impact is well in line with our regression results using alpha as the dependent variable. Also the effect of the log EBITDA multiple stays significant and has nearly the same size. A $10 \%$ multiple increase from entry to exit shifts the PME by $12 \%$.

We conclude that it is the improvement in margins and multiples that distinguishes good deals from others in terms of value creation. This is potentially an important result: it provides insight into the operating strategies that might be at play in different PE deals and thereby offers a lens to isolate those strategies (most likely, margin improvements or profitability turnarounds) that lead to greater abnormal performance.

\section{Active ownership}

We now discuss the final piece of our analysis, which is based on qualitative deal-level information on governance and active ownership practices of PE houses, collected through interviews with general partners involved in specific deals. 


\subsection{Private equity versus PLC model of governance: A summary}

In terms of overall governance mechanisms and modi operandi of boards, Table 9 provides the overall set of striking differences we gathered between the PE and PLC models of governance. For the PLC model of governance, we used data obtained from Spencer Stuart's 2005 Board Index for the top 150 firms in the UK, out of which we picked a size quintile that matched the average size of PE deals in our sample, and from Korn Ferry's $33^{\text {rd }}$ Annual Board of Directors Study for publicly listed firms in the UK.

Table 9 shows that PE boards are smaller than PLC boards by about two members. More importantly, non-executive directors (NXDs) in PLCs constitute about 50\% of the board, the rest being corporate insiders, whereas in PE boards, management is about $43 \%$ but of the remaining 57\%, 33\% are PE staff (who are technically NXDs but very different as we argue below) and the rest being NXDs. The NXDs in PLCs have little exposure to cash flow risk of the firm on the upside as they have little, if any, equity or options-based compensation; they are perhaps more exposed to the downside reputation risk. In contrast, the PE houses own (or manage for their limited partners, to be precise) over $75 \%$ of the equity on average in their portfolio companies, the remainder being owned by management and employees (15\%), other PE houses and limited partners (LPs) who co-invest in some deals. The PE houses are thus highly incentivized and empowered in terms of voting rights to effect substantial change at a rapid pace. Given these strong incentives, almost 1.5 FTE GP time is spent by the PE house on deals they manage at the due-diligence stage and 0.4 FTE GP time during the $1^{\text {st }} 100$ days. The GPs engage through weekly, often informal meetings with the management during the due-diligence phase and the first 100 days when value-creation plans are set for the next 3-4 years. In contrast, PLC boards are more focused on compliance issues and less on valuecreation strategies. PLC boards meet eight to ten times a year in formal meetings, with NXDs spending on average around 20 hours per month on firms they have board seats on. Top management in PE-run firms own around 15\% of ordinary equity (CEO owns around 6\%) in our sample and also co-invest, that is, buy the equity; such co-investment is rare in PLCs. Management in PE companies also face greater turnover risk. There is turnover in over 69\% 
of our deals during the private phase, which implies an average tenure of about 2 years, whereas the average CEO service in PLCs is longer at around 4.7 years. Finally, cutting costs is an explicit part of the value-creation plan in many PE deals, especially during the $1^{\text {st }} 100$ days, whereas only $36 \%$ of PLC boards rate themselves as focused (and good) at cost reduction. ${ }^{25}$

\subsection{Active ownership}

In this section, we provide evidence showing that the abnormal performance of PE deals correlates with active ownership and governance approach of PE funds and GPs involved with these deals. Since information on such practices is soft and not hard-coded in PE funds' documents, we conducted interviews to tabulate these changes and translate them into "governance scores" that we could relate to deal performance. More specifically, we interviewed in-depth general partners (GPs) involved in 48 of our 66 deals, essentially wherever the relevant GPs had not left the PE house in question. ${ }^{26}$

To start with, we provide in Figure 1 a schematic of the active ownership practices we found PE houses to deploy based on our interviews and conversations with them. Broadly speaking, these practices can be decomposed as:

(1) Due diligence during the phase prior to acquisition, which often involves intensive dialogue with existing board members, management and experts in the target company's domain;

(2) Drafting of value-creation (“100-day”) plans that serve as the initial blue-print of a company's strategic and operational agenda for its life in private ownership;

\footnotetext{
${ }^{25}$ Acharya, Kehoe and Reyner (2008) interviewed 20 executives in the UK who have been members of both PE and PLC boards of relatively large companies. The main differences they found in PE and PLC board modus operandi seem to be in the single-minded value creation focus of PE boards versus governance compliance and risk management focus of PLC boards. PE boards see their role as "leading" the strategy of the firm through intense engagement with top management; in contrast, PLC boards "accompany" the strategy of top management. PE boards report almost complete alignment in objectives between executive and non-executive directors, whereas the PLC boards report lack of complete alignment and focus on management of broader stakeholder interests. Finally, PE board members receive information that is primarily cash-focused and undergo an intensive induction during the due diligence phase. In contrast, PLC board members collect more diverse information and undergo a more structured (formal) rather than an intense induction.

${ }^{26}$ In total we conducted 57 interviews for the 66 deals. However, due to time constraints of the deal partners only in 48 interviews at least half of the questionnaire was covered.
} 
(3) Early management changes in order to replace ineffective management and bring in others who can execute the value-creation plan efficiently;

(4) Provision of substantial, but focused incentives, using significant equity and options-based stakes for top management (and often even to other employees), requiring coinvestment from top management and subjecting management to key performance indicators (KPIs);

(5) Investing significant GP time upfront, both in due diligence as well as in the first 100 days, and by interacting with the CEO and CFO, often multiple times a week through formal as well as informal channels; and,

(6) Employing external support where required to strengthen the company's weak spots in operations, and to implement required changes.

These practices constitute the most active phase of engagement by GPs involved with their portfolio companies, in the early phase. During the life of the deal, the value-creation plans are often refined based on newly acquired information, the top management team is monitored on a regular basis in terms of their performance through precise systems and processes, and plan deviations are reacted to immediately - operationally as well as through management changes - if necessary.

Before we start linking alpha to a specific set of interview answers, Table 10 summarizes those insights gathered from the interviews that we found most interesting.

(1) In terms of actual governance initiatives 39\% (33\%) of our deals have CEO (CFO) replacement in the first 100 days, and 69\% (61\%) have such replacement at some point during the deal.

(2) More than half of the deals start an organic growth and/or productivity initiative already in the first 100 days. In comparison, strategic repositioning initiatives are rather seldom.

(3) Revisions to the value-creation plan occur infrequently. Furtheremore, they are rarer during the $1^{\text {st }} 100$ days compared to the pre-closure phase. 
(4) In $68 \%$ of the cases, there is at least one board meeting a month and in $92 \%$ of the cases the GPs have regular, informal interactions with the CEO in the first 100 days at a weekly or better frequency. The total FTE committed is 2.96 in due diligence (1.44 being from GPs), 0.73 during the first 100 days (0.41 from GPs) and $0.41(0.25)$ thereafter, suggesting that on average 1.5 GPs are involved with new deals. Clearly, the time commitment by the PE funds is impressive given that a mature deal has only about one-fourth of a GP assigned to it. If we view GPs as NXDs of the board as well, then these time commitments represent highly intense engagement of board members during the early phase of PE deals.

(5) Incentive provision is high-powered as well: the PE house(s) own over 70\% of a deal's ordinary equity on average, with $14.6 \%$ of the remaining ordinary equity being employed for incentive purposes. The CEO is awarded on average $5.7 \%$ of the deal's ordinary equity and the rest of the management team gets $8.9 \%$. In terms of total equity (including preferred equity which is generally with the PE house), the CEO gets $1.2 \%$ and the rest of the management team $1.8 \%$. The high-powered nature of incentives is also reflected in the fact that on average the top management get a cash multiple of 13.5 on their cash investment in the deal (almost always, there is co-investment) upon hitting the base case of performance laid out in the value-creation plan.

(6) A PE firm's typical board structure has about eight members, with 33\% of them being PE staff (typically always the GP(s) involved in the deal), 43\% from the management team, and the rest in the form of NXDs who are not PE staff.

(7) Finally, external support/expertise is employed during the due diligence in $78 \%$ of the deals, in $29 \%$ during the first 100 days as well and in $42 \%$ at some point after the first year; $30 \%$ of the deals involve a major overhaul of the portfolio company in the valuecreation plan for the first 100 days with another 19\% involving minor changes.

\subsection{Active ownership index}

In order to put more structure on the collected interview information, we identified 21 questions to which the answers implied either relatively active or inactive governance. These 
21 questions, which we grouped into 7 active governance scores, are reported in Table 11, Panel A. Each answer was awarded a score of either 100 (active) or 0 (inactive), and the 21 questions were compiled into seven groups, each containing three related questions. Due to time constraints, $14 \%$ of all questions were not answered. As a result, when we derived the subtotals for each of the seven groups, we filled the data holes with the cross-sectional average and normalised the subtotals by dividing the total score (ranging from 0 to 300) by 3 and the grand total (ranging from 0 to 2100) by 21,. However, when employing each question individually we did not fill the blanks and the number of observations does not always sum up exactly to 48.

\subsection{Governance and alpha}

We are interested in knowing if variation in active governance across deals is linked to corresponding variation in enterprise-level abnormal performance of the deals. Table 11, Panel B provides preliminary evidence on how the governance scores vary between the average and the top tercile deals in terms of alpha. Overall, the top third has a higher active ownership activity level than the average deal (score of 63 versus 59). Although this difference is not significant, top alpha deals have only in 1 out of the 7 active governance scores a lower mean score than the average of the deals. In particular, the question on management incentive depth (size of the cash multiple) is statistically significant lower for the top tercile of alpha deals $(\mathrm{t}=-2.0) .^{27}$

Importantly, top tercile alpha deals have statistically significantly higher scores for management support $(t=2.2)$ and external support $(t=2.6)$, implying that for successful deals, weekly interaction with the CEO and interactions with the CFO happen more frequently than on average. Furthermore, these deals leverage extensively more external support in the due diligence and within the first 100 days. External support is usually brought

\footnotetext{
27 There are two possible interpretations: (i) strengthening of the management team through appropriate replacements in the early phase delivers performance, but providing them with strong equity-based incentives and requiring them to co-invest does not; or, (ii) strong incentives are provided because weaker incentives would result in even lower performance. That is, the worst deals are so risky that strong incentive provision required to attract good managers and improve performance fails to improve these deals substantially enough to push their performance above that of other deals.
} 
about to cut costs and improve process efficiency, which contribute to margin improvements, and are often not the focus of non-PE firms. Overall it seems that PE governance overcomes the principal-agent problems at portfolio companies with management through an "encourage” (external support) and “challenge" (intense monitoring) approach.

In Table 11, Panel C, we perform multivariate regression analysis that links the 7 active governance scores to alpha. The first set of results relates each score individually to alpha, whereas the second set reports the best regression obtained from employing several scores together. All regressions control for duration, entry time period and size of deals as well as for inorganic strategies and not exited deals. Across the individual and joint regressions, we find that again management support and external support explain alpha best. Additionally early management changes are significantly positively related to alpha in specification (9) when all governance scores are employed together. While this does not necessarily imply that management change and support and efforts in monitoring the management of the PE house automatically lead to value creation, it is suggestive of the critical agency problem that may be unlocked by successful PE houses for value creation through: changing or challenging entrenched management in PLCs; taking private and monitoring the inefficiently managed subsidiaries of conglomerates; professionalization of small family-owned businesses by bringing in expertise from the deal partners; and so on.

For the sake of completeness we also checked if our results are robust to alternative financial performance measures, namely a) PME based on sector or b) PME on market returns or c) IRR. The active governance scores corresponding to intensity of engagement and leveraging of external support remain significant with a positive impact (results available upon request).

\subsection{Governance and operating performance}

In Table 12, Panel A, we perform again a non-parametric analysis on the governance scores, but this time we are linking the 21 governance questions to operational improvements. The first column starts with the average per question for all deals ( $n=48$ ), the second shows the average for the organic deals only $(n=26)$ and the third for the subset of organic deals that 
improved margin on average during PE ownership more than the sector $(n=8)$. We focus on organic deals, since acquisition or divestments add noise to the operational figures, for which we can not control for in this univariate test setting.

First, it is striking that the scores are growing monotone from the first to the third column for the total (from a score of 59 to 62 to 68), for all of the 7 active governance scores and for nearly every question. And second, although the sample size for the margin outperformers is small and the organic deals are on average already more active, the margin outperformers show in some active governance scores even higher activity level. We also find it promising, in light of our overall conclusions from the relationship between governance and alpha, that active governance score 4 (management support) and 7 (external support) also show up higher for margin outperformers. In addition, the management changes show up as borderline significant, and also, a separation of Chairman and CEO positions seems to be related to success.

Interestingly the organic deals and in particular the margin outperformers (with a response rate of $100 \%$ ) focus on productivity initiatives more frequently. We therefore provide more detail on the productivity initiatives in Table 12, Panel B. Margin outperformers show in 3 out of 5 productivity initiatives a higher level of activity. Nearly half of the margin outperformers initiate in the first 100 days an overhead reduction program, in contrast to the average of organic deals of $11 \%$. In addition, working capital and purchasing initiatives show up as much more frequent than average.

\section{Concluding remarks}

The surge in private equity funding during 2003 through to the middle of 2007, and the aftermath of the sub-prime crisis since then, has brought research on private equity to confront similar issues as those after the boom and bust cycles of late 80s and early 90s. From an economic standpoint, the primary interest concerns the long-run viability and value creation, if any, from the private ownership of leveraged buyouts. On the policy front, the PE industry has attained a significant status in terms of the number of employees working in PE- 
funded enterprises at some point and, as a result, has attracted a certain amount of media as well as regulatory scrutiny. While some of this scrutiny is centred around whether tax rates on carry earned by PE houses is "fair", significant policy interest has also been expressed in understanding and quantifying the long-run impact of private equity in terms of value creation at the enterprise level, and in the attribution of this value creation to financial engineering, systematic risk and operational engineering. Indeed, in some cases such as in the UK, policymakers have undertaken independent recommendations based on interactions with the $\mathrm{PE}$ industry to improve disclosure on such value attribution. ${ }^{28}$

This paper is best viewed as an attempt to get at some of these issues with three significant contributions. First, we provided a simple methodology that relies only on returns and leverage information at the level of deal's equity, and the returns and leverage of quoted peer firms in order to extract a measure of abnormal performance of the deal ("alpha”) at enterprise-level. The methodology also quantifies the sector and leverage contributions to deal return. Second, we showed using this measure that for 66 deals of twelve large, mature PE houses in the UK initiated during the period 1996-2004, there is evidence consistent with significant value creation for portfolio companies. Furthermore, deal-level alpha outperformance is stronger during sector downturns and correlates well with operating outperformance of deals relative to quoted peers, measured as improvement in margins and multiples relative to the quoted sector. Third, we provided evidence based on interviews with GPs involved in PE deals that implied that the abnormally positive performance of these PE houses is at least partly due to active ownership and governance they engage in.

Our results can be interpreted as providing a microscopic view on expertise in operational engineering employed by large, mature PE houses in turning around companies they acquire. Returns to this expertise are likely the reason behind persistent and significant out-performance of funds run by these houses.

\footnotetext{
${ }^{28}$ See the House of Commons Treasury Committee's Tenth Report in the UK of Session 2006-07 and Sir David Walker Report on “Disclosure and Transparency in Private Equity” (2007).
} 
However, much remains to be done on this front. First, the comparison group has to be assembled more carefully than using the 3 digit sector code, since PE deals differ significantly from their sector peers in terms of profitability and size. Therefore, we match in ongoing work sector peers to each deal via a propensity-score methodology, based on the preacquisition accounting measures. Using these peers, we find stronger evidence of value addition by private equity firms. Second, a considerable interest remains in understanding in greater depth the nature of engagement and involvement of PE houses with portfolio companies and providing more robust evidence on how these relate to value creation. Larger, deal-level datasets prepared with the help of the PE industry are clearly required for this interest to be fulfilled by researchers. Finally, designing creative ways of understanding short-run and long-run investment impacts of the PE industry relative to other firms in the economy remains an important area to explore. The patent-based innovation analysis of PE companies undertaken by Lerner, Sorensen and Stromberg (2008) seems an exciting start on this front and suggests that PE deals generate not just productive but also innovative growth. 


\section{References}

Acharya, Viral, Conor Kehoe and Michael Reyner (2008), "Private Equity versus PLC Boards: A Comparison of Practices and Effectiveness", Journal of Applied Corporate Finance, forthcoming.

Acharya, Viral, Julian Franks and Henri Servaes (2007), “Private Equity: Boom and Bust?”, Journal of Applied Corporate Finance, 19(4), 44-53.

Amess, K.; Wright, M. (2007). "The Wage and Employment effects of leveraged buyouts in the UK", International Journal of the Economics of Business, Vol.14 (2), pp. 179-195.

Amess, K.; Girma, S. and Wright, M. (2008). "What are the Wage and Employment Consequences of Leveraged Buyouts, Private Equity and Acquisitions in the UK?", NBUS Research Paper Series No. 2008-01.

Axelson, U., Per Stromberg and Michael Weisbach (2007), "Why are buyouts leveraged? The financial structure of private equity funds", working paper, Swedish Institute for Financial Research.

Axelson, U., Jenkinson, T.J., Stromberg, P. and Weisbach, M. (2008), "Leverage and Pricing in Buyouts: An Empirical Analysis”, working paper, Swedish Institute for Financial Research.

Carhart, Mark. (1997) “On Persistence in Mutual Fund Performance”, Journal of Finance, 52(1), 57-82.

Cao, J., and J. Lerner. 2006. "The Performance of Reverse Leveraged Buyouts.” NBER Working Paper No. 12626.

Davis, Steven, John Haltwinger, Ron Jarmin, Josh Lerner and Javier Miranda. (2008) "Private Equity and Employment”, Working Paper, University of Chicago.

Guo, Shourun, Hotchkiss, Edith S. and Song, Weihong, (2007) "Do Buyouts (Still) Create Value?", Working Paper, Boston College.

Harris, R.; Siegel, D.; Wright, M. (2005). "Assessing the Impact of Management Buyouts on Economic Efficiency: Plant-Level Evidence from the United Kingdom", Review of Economic and Statistics, Vol.87, pp. 148-153.

Heel, Joe and Conor Kehoe. (2004) “Active Ownership in PE - How Do They Do It?”, McKinsey \& Co.

Jensen, Michael, 1989, Eclipse of the public corporation, Harvard Business Review, Sept.Oct., 61-74.

Jones, Charles M. and Rhodes-Kropf, Matthew, "The Price of Diversifiable Risk in Venture Capital and Private Equity" (May 2003). AFA 2003 Washington, DC Meetings.

Kaplan, Steven, 1989, The effects of management buyouts on operations and value, Journal of Financial Economics 24, 217-254. 
Kaplan, S.N., and A. Schoar. 2005. "Private Equity Performance: Returns, Persistence, and Capital Flows.” Journal of Finance, vol. 60, no. 4 (August):1791-1823.

Kaplan, Steven and Jeremy Stein, 1993, "The Evolution of Buyout Pricing and Financial Structure in the 1980s," Quarterly Journal of Economics, Volume 108, May, 1993, 313-358.

Kaplan, Steven and Per Stromberg, 2008, "Leveraged Buyouts and Private Equity”, Journal of Economic Perspectives, forthcoming.

Lerner, J., and A. Schoar. 2004. "The Illiquidity Puzzle: Theory and Evidence from Private Equity.” Journal of Financial Economics, vol. 72, no. 1 (April):3-40.

Lerner, J., A. Schoar, and W. Wong. 2007. Forthcoming. "Smart Institutions, Foolish Choices? The Limited Partner Performance Puzzle.” Journal of Finance.

Lerner, J., M. Sorensen, and P. Stromberg, 2008. "Private Equity and Long-Run Investment: The Case of Innovation,” Working Paper, Stockholm School of Economics.

Leslie, Phillip and Paul Oyer, 2008. "Managerial Incentives and Value Creation: Evidence form Private Equity”, Working paper, Stanford-GSB.

Lichtenberg, Frank and Donald Siegel, 1990, The effects of leveraged buyouts on productivity and related aspects of firm behaviour, Journal of Financial Economics, volume 27 (1990) 165-194.

Ljunqvist, A., M. Richardson and D. Wolfenzon, 2007, “The Investment Behavior of Buyout Funds: Theory and Evidence”, Working Paper, Stern School of Business, New York University.

Metrick, A. and A. Yasuda, 2007, "Economics of Private Equity Funds”, Working Paper, Wharton Business School.

Nikoskelainen, E.; Wright, M.(2007)., "Value Creation and Corporate Governance in Leveraged Buy-outs", Journal of Corporate Finance, forthcoming 2007.

Palepu, Krishna G., 1990, Consequences of leveraged buyouts, Journal of Financial Economics 27, 247-262.

Phalippou, L., 2007. "Investing in Private Equity Funds: A Survey.” Working paper, University of Amsterdam.

Phalippou, L., and O. Gottschalg. 2007. "The Performance of Private Equity Funds." Working paper, University of Amsterdam and HEC Paris.

Renneboog, L.; Simons, T.; Wright, M.(2007)., "Why do firms go private in the UK?", Journal of Corporate Finance, forthcoming 2007.

Smith, Abbie, 1990, Corporate ownership structure and performance: The case of management buyouts, Journal of Financial Economics, volume 27 (1990) 143-164. 
Figure 1: Timeline of active governance in a typical private equity transaction

Company outperformance driven by active ownership practices deployed mainly before or right after acquisition

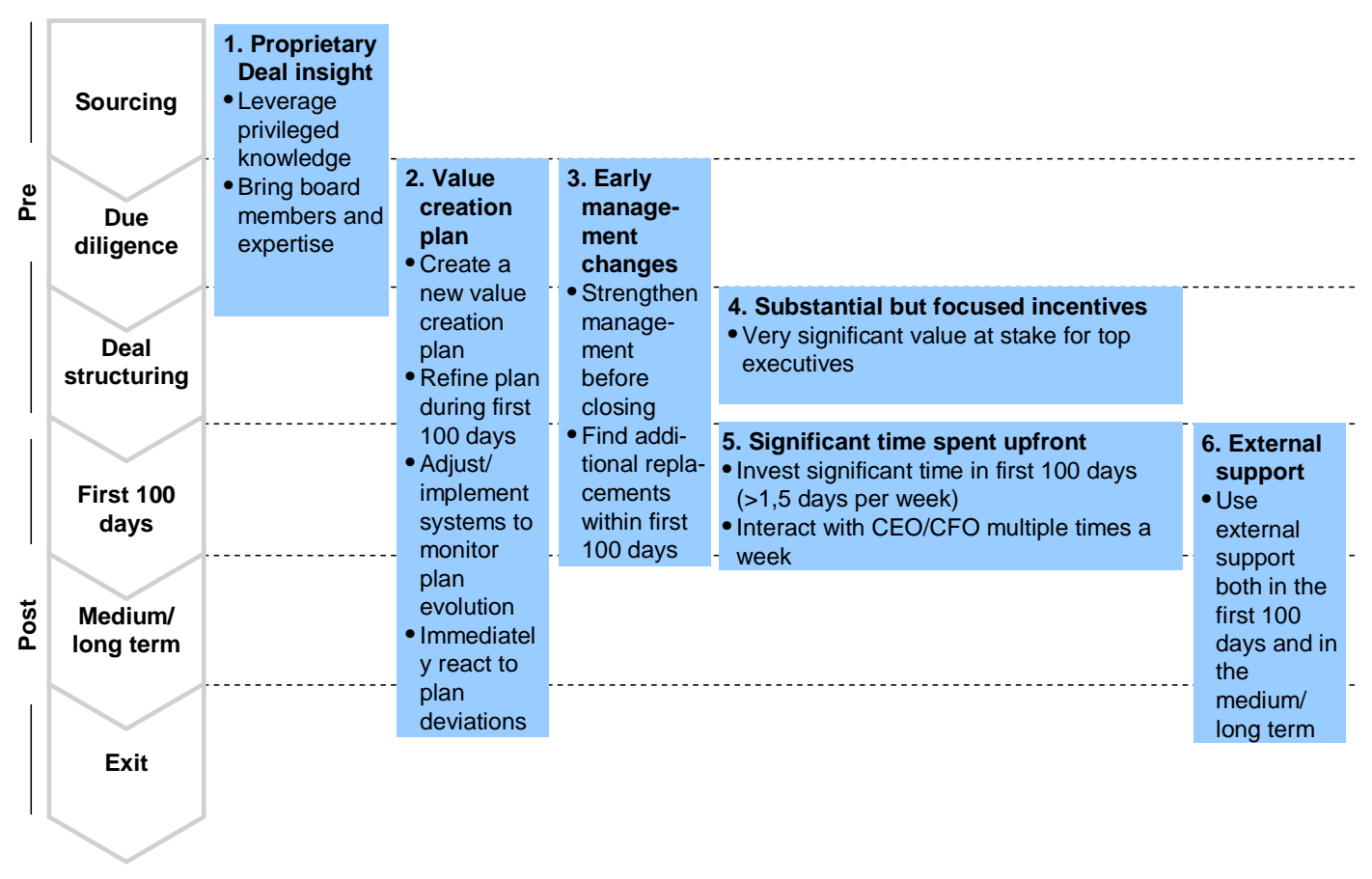


Table 1 - Panel A: Distribution of deals by entry and exit years

\begin{tabular}{lllllllllllll}
\hline \hline Years & 1996 & 1997 & 1998 & 1999 & 2000 & 2001 & 2002 & 2003 & 2004 & 2005 & 2006 & 2007 \\
\hline Entry & 2 & 5 & 7 & 9 & 8 & 6 & 10 & 12 & 7 & n/a & n/a & n/a \\
Exit & n/a & n/a & n/a & n/a & 2 & 4 & 6 & 6 & 10 & 14 & $19^{1}$ & 5 \\
\hline
\end{tabular}

1 Including six deals for which exit is simulated

Table 1 - Panel B: Summary statistics

\begin{tabular}{|c|c|c|c|c|c|c|c|}
\hline Variable & $\mathbf{n}$ & mean & median & $\begin{array}{l}\text { std. } \\
\text { dev. }\end{array}$ & $\min$ & $\max$ & $\begin{array}{l}\text { t-stat of diff. } \\
\text { exit and entry }\end{array}$ \\
\hline Deal IRR \% & \multirow{2}{*}{66} & 35.5 & 32.5 & 45.1 & -72.5 & 197.4 & $\mathrm{n} / \mathrm{a}$ \\
\hline Cash in/cash out multiple & & 2.8 & 2.5 & 1.9 & 0 & 10.3 & $\mathrm{n} / \mathrm{a}$ \\
\hline Duration $^{1}$ (years) & 60 & 3.8 & 3.6 & 1.5 & 1.2 & 7.3 & $\mathrm{n} / \mathrm{a}$ \\
\hline Deal size entry (Mio, EUR) ${ }^{1}$ & \multirow{2}{*}{60} & 794 & 486 & 778 & 110 & 3155 & \multirow{2}{*}{$5.3 * * *$} \\
\hline Deal size exit (Mio, EUR) ${ }^{1}$ & & 1,252 & 781 & 1,252 & 64 & 4,970 & \\
\hline Deal size/EBITDA (Entry) ${ }^{2}$ & \multirow{2}{*}{53} & 9.0 & 8.2 & 4.8 & 2.7 & 34.8 & \multirow{2}{*}{$2.4^{* *}$} \\
\hline Deal size/EBITDA (Exit) ${ }^{2}$ & & 10.9 & 10.1 & 4.5 & 3.4 & 23.1 & \\
\hline Debt/equity (Entry) ${ }^{2}$ & \multirow{2}{*}{60} & 1.7 & 1.6 & 0.8 & 0.1 & 5.2 & \multirow{2}{*}{$-5.8 * * *$} \\
\hline Debt/equity (Exit) ${ }^{2}$ & & 0.9 & 0.6 & 0.9 & 0 & 5.1 & \\
\hline Debt/EBITDA (Entry) ${ }^{2}$ & \multirow{2}{*}{53} & 5.5 & 5.1 & 3.9 & 0.3 & 29.1 & \multirow{2}{*}{-1.0} \\
\hline Debt/EBITDA (Exit) ${ }^{2}$ & & 4.8 & 4.0 & 3.6 & 1.0 & 22.7 & \\
\hline
\end{tabular}

Note: Significance level $* \mathrm{p}<0.1, * * \mathrm{p}<0.05, * * * \mathrm{p}<0.01$

1 Only exited deals

2 Only exited deals and if EBITDA for exit and entry date available (including bankruptcies) 
Table 2 - Panel A: Benchmarking of sample by distribution of deal size:

\begin{tabular}{llllllll}
\hline \hline & & \multicolumn{3}{c}{ Size of deal } & & total & \multicolumn{2}{c}{$\begin{array}{c}\text { coverage for } \\
\text { deals }>\mathbf{1 0 0} \text { Mio }^{1}\end{array}$} \\
\cline { 2 - 5 } & & $\mathbf{0 - 9 9}$ & $\mathbf{1 0 0 - 5 0 0}$ & $>\mathbf{5 0 0}$ & & \\
\hline \multirow{2}{*}{ Our sample } & Per number of deals & $0 \%$ & $50 \%$ & $50 \%$ & 66 & $19.9 \%(66 / 350)$ \\
\cline { 2 - 6 } & Per deal value (EV) & $0 \%$ & $16 \%$ & $84 \%$ & 52 & $31.5 \%(52 / 165)$ \\
\hline \hline \multirow{2}{*}{ UK sample } & Per number of deals & $83 \%$ & $13 \%$ & $4 \%$ & 2,086 & $\mathrm{n} / \mathrm{a}$ \\
\cline { 2 - 6 } & Per deal value (EV) & $18 \%$ & $27 \%$ & $56 \%$ & 200 & $\mathrm{n} / \mathrm{a}$ \\
\hline
\end{tabular}

$1 \mathrm{EV}$ in Mio, EUR

Table 2 - Panel B: Benchmarking of sample by net IRR comparison

\begin{tabular}{|c|c|c|c|c|c|c|c|}
\hline & & $\mathbf{n}$ & $\begin{array}{l}\text { mean } \\
\text { net } \\
\text { IRR }^{1}\end{array}$ & $\begin{array}{l}\text { median } \\
\text { net } \\
\text { IRR }\end{array}$ & fund size & $\begin{array}{l}\text { vint } \\
\text {-age } \\
\text { year }\end{array}$ & $\begin{array}{l}\text { acq. } \\
\text { time } \\
\text { span }\end{array}$ \\
\hline \multirow{3}{*}{$\begin{array}{l}\text { Our } \\
\text { sample }\end{array}$} & All deals & 66 & 25.6 & 24.0 & \multirow{3}{*}{$500-5000$} & \multirow{3}{*}{$\begin{array}{l}94- \\
03\end{array}$} & \multirow{3}{*}{$\begin{array}{l}96- \\
04\end{array}$} \\
\hline & All deals pooled ${ }^{2}$ in 1 pseudo fund & 66 & 24.2 & $\mathrm{n} / \mathrm{a}$ & & & \\
\hline & All funds, reported fund NET IRR & 28 & 26.0 & 24.0 & & & \\
\hline \multirow{2}{*}{$\begin{array}{l}\text { UK } \\
\text { sample }\end{array}$} & All funds & 113 & 18.3 & 11.9 & $0-1000+$ & \multirow{2}{*}{$\begin{array}{l}94- \\
03\end{array}$} & \multirow{2}{*}{$\mathrm{n} / \mathrm{a}$} \\
\hline & All funds, with same size & 44 & 25.3 & 19.9 & $500-1000+$ & & \\
\hline
\end{tabular}

Note: All values in percent, Mio EUR

Source: Thomson Financial Venture Expert

1 Simple Average, NET IRR, estimated for our sample with $2 \%$ annual fees, and $20 \%$ carry if IRR larger than assumed benchmark of $8 \%$ market return

2 Pooled by calendar period using quarterly cash flows 
Table 3 - Panel A: IRR decomposition

\begin{tabular}{|c|c|c|c|c|c|c|}
\hline$\#$ & assumptions & IRR components & $\begin{array}{l}\text { IRR } \\
\text { gross }\end{array}$ & $\begin{array}{l}\text { share of } \\
\text { total } \\
\text { IRR }\end{array}$ & $\begin{array}{l}\text { medi } \\
\text { an }\end{array}$ & $\begin{array}{l}\text { std. } \\
\text { dev. }\end{array}$ \\
\hline \multirow[t]{4}{*}{ (1) } & \multirow{4}{*}{$\begin{array}{l}\mathbf{N}=\mathbf{6 6}, \\
\beta=1, \\
D / E_{i}=\text { deal } \\
\text { average, } \\
R_{\text {D.i }}=5.0\end{array}$} & $\begin{array}{l}\text { Deal-level abnormal performance } \\
\text { (alpha) }\end{array}$ & $8.9 * * *$ & 25.1 & 9.3 & 23.2 \\
\hline & & Return from incremental leverage ${ }^{2}$ & $15.5^{* * *}$ & 43.6 & 11.5 & 27.3 \\
\hline & & Levered sector return $^{1}$ & $11.1 * * *$ & 31.3 & 8.5 & 15.9 \\
\hline & & Total IRR & $35.5 * * *$ & 100.0 & 32.5 & 45.1 \\
\hline \multirow[t]{4}{*}{$(2)^{3}$} & \multirow{4}{*}{$\begin{array}{l}\mathbf{N}=\mathbf{6 0}, \\
\beta=1, \\
D / E_{i}=\text { deal } \\
\text { average, } \\
R_{D . i}=5.0\end{array}$} & $\begin{array}{l}\text { Deal-level abnormal performance } \\
\text { (alpha) }\end{array}$ & $9.1 * * *$ & 25.4 & 9.3 & 23.5 \\
\hline & & Return from incremental leverage ${ }^{2}$ & $16.4 * * *$ & 45.7 & 13.2 & 27.6 \\
\hline & & Levered sector return ${ }^{1}$ & $10.4^{* * *}$ & 28.8 & 7.8 & 16.2 \\
\hline & & Total IRR & $35.9 * * *$ & 100.0 & 32.5 & 46.2 \\
\hline \multirow[t]{4}{*}{$(3)^{4}$} & \multirow{4}{*}{$\begin{array}{l}\mathbf{N}=\mathbf{1 5}, \\
\beta=1, \\
D / E_{i}=\text { deal } \\
\text { average, } \\
R_{D . i}=5.0\end{array}$} & $\begin{array}{l}\text { Deal-level abnormal performance } \\
\text { (alpha) }\end{array}$ & $17.7^{*}$ & 65.8 & 14.3 & 35.4 \\
\hline & & Return from incremental leverage ${ }^{2}$ & 16.8 & 62.5 & 10.9 & 41.5 \\
\hline & & Levered sector return $^{1}$ & $-7.6 * * *$ & -28.2 & -5.4 & 7.9 \\
\hline & & Total IRR & 27.0 & 100.0 & 25.1 & 64.6 \\
\hline \multirow[t]{4}{*}{ (4) } & \multirow{4}{*}{$\begin{array}{l}\mathrm{N}=66, \\
\beta=1, \\
\mathrm{D} / \mathrm{E}_{\mathrm{i}}=\mathrm{deal} \\
\text { average, } \\
\mathbf{R}_{\mathbf{D .} \mathbf{i}}=\mathbf{7 . 5}\end{array}$} & $\begin{array}{l}\text { Deal-level abnormal performance } \\
\text { (alpha) }\end{array}$ & $9.7 * * *$ & 27.4 & 10.4 & 23.2 \\
\hline & & Return from incremental leverage ${ }^{2}$ & $14.7 * * *$ & 41.3 & 10.9 & 27.1 \\
\hline & & Levered sector return ${ }^{1}$ & $11.1 * * *$ & 31.3 & 8.5 & 15.9 \\
\hline & & Total IRR & $35.5 * * *$ & 100.0 & 32.5 & 45.1 \\
\hline \multirow[t]{4}{*}{ (5) } & \multirow{4}{*}{$\begin{array}{l}\mathrm{N}=66, \\
\beta=1, \\
\mathrm{D} / \mathrm{E}_{\mathrm{i}}=\text { deal } \\
\text { average, } \\
\mathbf{R}_{\mathbf{D .}}=\mathbf{2 . 5}\end{array}$} & $\begin{array}{l}\text { Deal-level abnormal performance } \\
\text { (alpha) }\end{array}$ & $8.1 * * *$ & 22.8 & 8.4 & 23.2 \\
\hline & & Return from incremental leverage ${ }^{2}$ & $16.3 * * *$ & 45.9 & 12.2 & 27.5 \\
\hline & & Levered sector return $^{1}$ & $11.1 * * *$ & 31.3 & 8.5 & 15.9 \\
\hline & & Total IRR & $35.5 * * *$ & 100.0 & 32.5 & 45.1 \\
\hline \multirow[t]{4}{*}{ (6) } & \multirow{4}{*}{$\begin{array}{l}N=66, \\
\beta=1, \\
D / E_{i}=\text { deal } \\
\text { entry, } \\
R_{D . i}=5.0\end{array}$} & $\begin{array}{l}\text { Deal-level abnormal performance } \\
\text { (alpha) }\end{array}$ & $8.0 * * *$ & 22.5 & 7.3 & 22.9 \\
\hline & & Return from incremental leverage ${ }^{2}$ & $16.4^{* * *}$ & 46.2 & 13.7 & 27.4 \\
\hline & & Levered sector return $^{1}$ & $11.1 * * *$ & 31.3 & 8.5 & 15.9 \\
\hline & & Total IRR & $35.5 * * *$ & 100.0 & 32.5 & 45.1 \\
\hline \multirow[t]{4}{*}{ (7) } & \multirow{4}{*}{$\begin{array}{l}\mathrm{N}=66, \\
\boldsymbol{\beta}=\mathbf{0 . 4 4}, \\
\mathrm{D} / \mathrm{E}_{\mathrm{i}}=\mathrm{deal} \\
\text { average, } \\
\mathrm{R}_{\mathrm{D} . \mathrm{i}}=5.0\end{array}$} & $\begin{array}{l}\text { Deal-level abnormal performance } \\
\text { (alpha) }\end{array}$ & $13.9 * * *$ & 39.3 & 12.9 & 21.7 \\
\hline & & Return from incremental leverage ${ }^{2}$ & $16.7 * * *$ & 46.9 & 12.5 & 27.0 \\
\hline & & Levered sector return $^{1}$ & $4.9 * * *$ & 13.8 & 3.8 & 7.0 \\
\hline & & Total IRR & $35.5 * * *$ & 100.0 & 32.5 & 45.1 \\
\hline
\end{tabular}

Note: All values in percent, significance level $* \mathrm{p}<0.1, * * \mathrm{p}<0.05, * * * \mathrm{p}<0.01$

1 Sector return reflects the market return and the additional return (over the market) by the comparable sectors over the deal period; 2 Return from effect a) the deal leverage beyond the sector leverage has on the sector returns and b) the total leverage has on enterprise-level abnormal performance (alpha); 3 Exited deals only; 4 Deals with negative sector returns only 
Table 3 - Panel B: Alpha vs. PME

\begin{tabular}{lllll}
\hline \hline & $\mathbf{n}$ & mean & median & std.dev. \\
\hline Alpha (scenario 1) & & 8.9 & 9.3 & 23.2 \\
IRR gross & 66 & 35.5 & 32.5 & 45.1 \\
PME Sector & & 106.0 & 95.5 & 161.0 \\
PME FTSE250 & & 173.2 & 142.7 & 188.8 \\
\hline Note: All values in percent & & & &
\end{tabular}

Note: All values in percent

Table 3 - Panel C: Correlation matrix: Alpha, IRR, PME Sector, PME FTSE250

\begin{tabular}{lllll}
\hline & n & IRR gross & PME Sector & $\begin{array}{l}\text { PME } \\
\text { FTSE250 }\end{array}$ \\
\hline Alpha (scenario 1) & & 72.3 & 66.5 & 45.4 \\
PME Sector & 66 & 62.6 & 100 & 76.1 \\
PME FTSE250 & & 73.7 & 76.1 & 100 \\
\hline
\end{tabular}

Note: All values in percent 
Table 4 - Panel A: Financial performance by deal types

\begin{tabular}{|c|c|c|c|c|c|c|c|}
\hline deal types & subdivisions & $\mathbf{n}$ & alpha & $\begin{array}{l}\text { t-stat of dif. } \\
\text { with mean } \\
\text { alpha }\end{array}$ & $\begin{array}{l}\text { IRR } \\
\text { gross }\end{array}$ & $\begin{array}{l}\text { PME } \\
\text { sector }\end{array}$ & $\begin{array}{l}\text { PME } \\
\text { FTSE } \\
250\end{array}$ \\
\hline \multirow[t]{2}{*}{ (1) syndication } & Club Deals & 25 & 14.3 & 0.3 & 40.4 & 94.7 & 146.9 \\
\hline & Non club deals & 41 & 5.7 & -0.3 & 32.7 & 113.9 & 190.4 \\
\hline \multirow[t]{3}{*}{ (2) deal size 4} & $>1$ billion Euro & 18 & 8.4 & -0.2 & 42.7 & 104.0 & 154.6 \\
\hline & $500 \mathrm{~m}-1$ billion Euro & 15 & 11.1 & 0.4 & 48.4 & 136.5 & 216.1 \\
\hline & 100m-499m Euro & 33 & 8.3 & -0.1 & 26.0 & 94.5 & 165.3 \\
\hline \multirow[t]{4}{*}{ (3) deal source } & Private non-PE & 20 & 5.8 & -0.6 & 38.9 & 115.9 & 239.1 \\
\hline & Private PE & 14 & 10.3 & 0.4 & 36.7 & 100.4 & 155.4 \\
\hline & Public subsidiary sold & 23 & 14.5 & 0.9 & 33.8 & 128.2 & 149.4 \\
\hline & Public total company & 9 & 0.0 & -1.6 & 31.3 & 40.6 & 120.7 \\
\hline \multirow[t]{6}{*}{ (4) exit type } & Sale to corporate & 18 & 16.2 & 1.0 & 47.9 & 175.9 & 204.9 \\
\hline & IPO & 16 & 12.4 & 0.8 & 49.5 & 112.7 & 238.2 \\
\hline & Merger & 2 & $-0,4$ & -0.7 & 37.5 & 36.3 & 109.7 \\
\hline & Sale to PE & 20 & 9.1 & 0.1 & 31.9 & 97.2 & 160.3 \\
\hline & Not exited in $2008^{1}$ & 6 & 6.6 & -0.3 & 30.9 & 53.8 & 143.6 \\
\hline & Bankruptcy & 4 & -30.7 & $-7.8 * * *$ & -52.8 & -77.6 & -85.4 \\
\hline \multirow[t]{3}{*}{ (5) deal strategy } & Deals with acquisitions & 17 & 3.4 & 1.3 & 28.6 & 123.0 & 210.1 \\
\hline & Deals with divestments & 13 & -2.7 & $-2.5^{* *}$ & 9.7 & 35.7 & 90.5 \\
\hline & Organic deals $^{2}$ & 36 & 15.8 & 1.6 & 48.5 & 124.5 & 200.0 \\
\hline \multirow[t]{4}{*}{ (6) leverage le $^{3}$} & High (1. quartile) & 16 & 8.7 & -0.1 & 37.8 & 105.5 & 176.1 \\
\hline & Medium high (2. quart.) & 17 & 5.1 & -0.7 & 44.0 & 150.9 & 237.4 \\
\hline & Medium low (3. quart.) & 16 & 4.8 & -0.9 & 21.7 & 69.3 & 107.1 \\
\hline & Low (4. quart.) & 17 & 16.8 & 1.0 & 37.7 & 96.2 & 168.4 \\
\hline \multirow[t]{4}{*}{ (7) entry type } & Auction & 36 & 12.8 & 0.9 & 42.4 & 138.7 & 217.6 \\
\hline & Privileged relation & 11 & 7.3 & -0.4 & 22.6 & 79.2 & 108.4 \\
\hline & Public & 7 & 2.0 & -0.9 & 45.3 & 52.8 & 159.7 \\
\hline & Other & 12 & 2.7 & -1.2 & 20.9 & 63.7 & 107.1 \\
\hline \multirow[t]{4}{*}{ (8) entry time } & 1994-97 & 7 & -0.6 & -0.9 & 23.4 & 31.7 & 150.6 \\
\hline & $1998-2000$ & 24 & 6.8 & -0.7 & 12.3 & 120.5 & 128.4 \\
\hline & $2001-02$ & 16 & 24.8 & $2.1 * *$ & 61.0 & 170.2 & 227.5 \\
\hline & 2003-04 & 19 & 1.7 & -1.7 & 47.7 & 61.1 & 192.3 \\
\hline Total & & 66 & 8.9 & & 35.5 & 106.0 & 173.2 \\
\hline \multicolumn{8}{|c|}{ Note: All values in percent (except $\mathrm{n}$ and $\mathrm{t}$-statistics) } \\
\hline \multicolumn{8}{|c|}{1 Exit simulated } \\
\hline \multicolumn{8}{|c|}{2 Organic deals are those where no major acquisition or divestment (M/A) was reported } \\
\hline \multicolumn{8}{|c|}{3 Leverage quartile sorted by leverage $(\mathrm{D} / \mathrm{E})$ at acquisition } \\
\hline
\end{tabular}


Table 5 - Panel A: Operating performance PRE PE ownership $(\mathbf{n}=\mathbf{5 4})^{1}$

\begin{tabular}{|c|c|c|c|c|c|c|}
\hline Variable & mean & median & $\begin{array}{l}\text { std. } \\
\text { dev. }\end{array}$ & $\min$ & $\max$ & $\begin{array}{l}\text { t-stat of } \\
\text { diff with } \\
\text { sector }\end{array}$ \\
\hline deal EBITDA & 92.3 & 51.1 & 94.7 & -11.7 & 331.9 & \multirow{2}{*}{$-7.0 * * *$} \\
\hline sector average EBITDA & 242.3 & 222.2 & 145.6 & 14.8 & 761.9 & \\
\hline deal sales & 596.0 & 329.8 & 670.0 & 22.1 & $2,965.8$ & \multirow{2}{*}{$-12.1 * * *$} \\
\hline sector average sales & $2,267.0$ & $2,188.9$ & $1,174.0$ & 61.2 & $4,715,7$ & \\
\hline deal margin in $\%$ & 18.8 & 16.5 & 11.6 & -6.5 & 69.1 & \multirow{2}{*}{$4.5 * * *$} \\
\hline sector average margin in $\%^{2}$ & 11.5 & 9.8 & 5.4 & 6.0 & 40.4 & \\
\hline deal enterprise value (EV) & 817.0 & 503.4 & 795.6 & 109.7 & $3,154.9$ & \multirow{2}{*}{$-6.6^{* * *}$} \\
\hline sector average EV & $2,386.3$ & $2,149.5$ & $1,629.5$ & 102.7 & $10,249.1$ & \\
\hline deal EBITDA multiple & 9.2 & 9.1 & 6.0 & -13.7 & 38.7 & \multirow{2}{*}{-0.7} \\
\hline sector average EBITDA multiple ${ }^{2}$ & 9.8 & 9.1 & 3.4 & 5.2 & 28.7 & \\
\hline deal FTE $(n=31)$ & 4,363 & 2,627 & 4,382 & 160 & 17,000 & \multirow{2}{*}{$-9.1 * * *$} \\
\hline sector average FTE $(n=31)$ & 16,950 & 17,360 & 7,835 & 5,093 & 28,964 & \\
\hline
\end{tabular}

Note: All values in Mio EUR, except EBITDA multiple, FTE and t-statistics, significance level $* \mathrm{p}<0.1, * * \mathrm{p}<0.05, * * * \mathrm{p}<0.01$

1 Calculated with a simple average across all years PRE PE ownership. On average are available 2.2 years of data PRE PE ownership. Conversion into EUR based on annual exchange rates

2 Weighted average: total sector EBITDA divided by total sales or total enterprise value

Table 5 - Panel B: Operating performance trends PRE PE ownership ${ }^{1}$

\begin{tabular}{|c|c|c|c|c|c|c|c|c|}
\hline & Variable & mean & $\begin{array}{l}\text { medi } \\
\text { an }\end{array}$ & $\begin{array}{l}\text { std. } \\
\text { dev. }\end{array}$ & $\min$ & $\max$ & t-stat & $\begin{array}{l}\text { t-stat of } \\
\text { diff with } \\
\text { sector }\end{array}$ \\
\hline \multirow{6}{*}{$\begin{array}{l}\text { All deals } \\
(n=38)\end{array}$} & deal sales growth ${ }^{3}$ & 8.7 & 6.3 & 13.0 & -11.3 & 52.5 & $4.1 * * *$ & \multirow{2}{*}{1.2} \\
\hline & sector sales growth ${ }^{3}$ & 5.5 & 3.1 & 10.0 & -14.8 & 48.8 & $3.5 * * *$ & \\
\hline & deal EBITDA growth ${ }^{3}$ & 10.1 & 9.4 & 20.1 & 33.6 & 66.2 & $3.1 * * *$ & \multirow{2}{*}{1.0} \\
\hline & sector EBITDA growth ${ }^{3}$ & 6.2 & 4.5 & 13.8 & 39.5 & 44.5 & $5.1 * * *$ & \\
\hline & deal margin ppt change & 0.0 & 0.0 & 2.3 & -8.1 & 7.0 & 0 & \multirow{2}{*}{-0.3} \\
\hline & sector margin ppt change & 0.1 & 0.2 & 0.8 & -3.1 & 1.8 & 0.8 & \\
\hline \multirow{6}{*}{$\begin{array}{l}\text { Organic } \\
\text { deals } \\
\text { only } \\
(n=20)^{2}\end{array}$} & deal sales growth ${ }^{3}$ & 7.5 & 5.8 & 12.6 & -10.8 & 52.5 & $2.7 * *$ & \multirow{2}{*}{0.9} \\
\hline & sector sales growth ${ }^{3}$ & 4.9 & 3.3 & 5.6 & -1.1 & 15.8 & $3.9 * * *$ & \\
\hline & deal EBITDA growth ${ }^{3}$ & 8.2 & 4.5 & 24.5 & 33.6 & 66.2 & 1.5 & \multirow{2}{*}{0.0} \\
\hline & sector EBITDA growth ${ }^{3}$ & 8.1 & 4.8 & 10.6 & 7.1 & 43.3 & $5.7 * * *$ & \\
\hline & deal margin ppt change & -0.5 & 0.3 & 2.8 & -8.1 & 7.0 & -0.7 & \multirow{2}{*}{-1.1} \\
\hline & sector margin ppt change & 0.2 & 0.3 & 0.5 & -1.0 & 1.8 & 1.7 & \\
\hline
\end{tabular}

Note: All values in percent p.a., except t-statistics

1 Deals are only included if at least two years of data before PE ownership are available.

2 Organic deals are those where no major acquisition or divestment (M/A) was reported

3 Nominal growth p.a., growth for deals calculated in local currency 
Table 6: Univariate Tests: Deals vs. Sector performance pre and during PE ownership

The Table reports for various operating measures $y$ the average cross-sectional difference $\Delta y_{i}=\bar{y}_{i, \text { durPE }}-\bar{y}_{i, \text { prePE }}$ from pre-acquisition to during PE-ownership period where (i) $\bar{y}_{i, \text { prePE }}$ measures the average of the variable pre-acquisition and $\bar{y}_{i, d u r P E}$ the average for the PE-ownership phase. For the sector margin and multiple we calculated a weighted average (total EBITDA divided by total sector sales or EV). The first column with t-statistics tests if $\Delta y_{i}$ for the deal is different from zero, the second if $\Delta y_{i}$ is different to $\Delta y_{s}$.

For growth, we calculate $\Delta^{2} y_{i}=\overline{\Delta y}_{i, d u r P E}-\overline{\Delta y}_{i, p r e P E}$ where $\overline{\Delta y}_{i, p r e P E}$ measures the change in the variable pre-acquisition, $\overline{\Delta y}_{i, \text { durPE }}$ the change during PE ownership phase.

\begin{tabular}{|c|c|c|c|c|c|c|}
\hline & Variable & $\bar{n}$ & $\begin{array}{l}\text { mean deal } \\
\Delta y_{i} \text { or } \Delta^{2} y_{i}\end{array}$ & $\begin{array}{c}\text { mean sector } \\
\Delta y_{s} \text { or } \Delta^{2} y_{s}\end{array}$ & $\begin{array}{l}\text { t-stat. } \\
\text { mean } \\
\text { deal }\end{array}$ & $\begin{array}{l}\text { t-stat. of } \\
\text { dif. with } \\
\text { sector }\end{array}$ \\
\hline \multirow{6}{*}{$\begin{array}{l}\text { All deals } \\
(n=66)\end{array}$} & Multiple $^{1}$ & 53 & 0.5 & 1.4 & 0.2 & -0.4 \\
\hline & Log multiple ${ }^{12}$ & 51 & 0.2 & 0.0 & $3.4^{* * *}$ & $2.2^{* *}$ \\
\hline & $\log _{\text {EBITDA }}^{2}$ & 53 & 0.3 & 0.2 & 0.6 & 0.6 \\
\hline & Log sales & 54 & 0.3 & 0.2 & $4.6 * * *$ & 1.6 \\
\hline & Margin in \% & 54 & 0.8 & 0.6 & 1.0 & 0.2 \\
\hline & Log FTE & 24 & 0.1 & 0.1 & 1.2 & 0.0 \\
\hline \multirow{6}{*}{$\begin{array}{l}\text { Inorganic } \\
\text { deals only } \\
(n=30)\end{array}$} & Multiple $^{1}$ & 25 & 2.9 & -0.3 & $2.3 * * *$ & $2.4^{* *}$ \\
\hline & Log multiple ${ }^{12}$ & 24 & 0.2 & 0.0 & $2.0^{*}$ & $1.9^{*}$ \\
\hline & $\log _{\text {EBITDA }}{ }^{2}$ & 25 & 0.2 & 0.3 & -0.5 & -0.5 \\
\hline & Log sales & 26 & 0.3 & 0.2 & $3.6 * * *$ & 1.0 \\
\hline & Margin in $\%$ & 26 & 0.5 & 0.7 & 0.5 & -0.2 \\
\hline & Log FTE & 14 & 0.1 & 0.1 & 1.3 & -0.3 \\
\hline \multirow{6}{*}{$\begin{array}{l}\text { Organic } \\
\text { deals only } \\
(n=36)\end{array}$} & Multiple $^{1}$ & 28 & -1.7 & 2.8 & -0.5 & -1.1 \\
\hline & Log multiple ${ }^{12}$ & 27 & 0.2 & 0.1 & $2.8 * * *$ & 1.3 \\
\hline & $\log _{\text {EBITDA }^{2}}$ & 28 & 0.4 & 0.2 & 1.6 & 1.6 \\
\hline & Log sales & 28 & 0.3 & 0.2 & $2.9 * * *$ & 1.2 \\
\hline & Margin in \% & 28 & 1.0 & 0.0 & 0.9 & 0.9 \\
\hline & Log FTE & 14 & 0.1 & 0.1 & 0.5 & 0.4 \\
\hline \multirow[t]{3}{*}{ All deals } & EBITDA growth p.a. in $\%^{2}$ & & $7.7 / 100$ & $2.2 / 100$ & $1.9^{*}$ & 1.0 \\
\hline & Sales growth p.a. in \% & $38^{3}$ & $3.2 / 100$ & $1.0 / 100$ & 1.3 & 0.7 \\
\hline & Margin ppt. change p.a. & & 0.7 & 0.2 & 1.5 & 1.0 \\
\hline \multirow{3}{*}{$\begin{array}{l}\text { Inorganic } \\
\text { deals only }\end{array}$} & EBITDA growth p.a. in $\%^{2}$ & & $3.3 / 100$ & $5.6 / 100$ & 0.6 & -0.3 \\
\hline & Sales growth p.a. in $\%$ & $18^{3}$ & $4.6 / 100$ & $1.7 / 100$ & 1.2 & 0.6 \\
\hline & Margin ppt. change p.a. & & -0.3 & 0.4 & -1.0 & 1.5 \\
\hline \multirow{3}{*}{$\begin{array}{l}\text { Organic } \\
\text { deals only }\end{array}$} & EBITDA growth p.a. in $\%^{2}$ & & $11.6 / 100$ & $-0.1 / 100$ & $1.9^{*}$ & $1.8^{*}$ \\
\hline & Sales growth p.a. in $\%$ & $20^{3}$ & $1.9 / 100$ & $0.5 / 100$ & 0.6 & 0.4 \\
\hline & Margin ppt. change p.a. & & 1.6 & 0.0 & $2.2^{* *}$ & $2.2^{* *}$ \\
\hline
\end{tabular}

Note: Significance level $* \mathrm{p}<0.1, * * \mathrm{p}<0.05, * * * \mathrm{p}<0.01$ 
1 Exited and non bankrupt deals only

2 Excluding observations with negative EBITDA

3 Deals are only included if at least two years of data before PE ownership are available 
Table 7 - Panel A: Analysis of PE impact on margin

The Table reports the estimated impact of PE on the EBITDA margin in the following way:

$$
\begin{aligned}
& \overline{\text { margin }}_{i, \text { durPE }}-\overline{\text { margin }}_{i, \text { prePE }}=\beta_{1} P E_{i}+\beta_{2} \text { PEduration }_{i}+\beta_{3} \text { inorganic }_{i}+\beta_{4} \text { bankrupt }_{i}+\beta_{5} \text { unexited }_{i} \\
& +\beta_{6}\left({\overline{\text { sector } \text { margin }_{i, \text { durPE }}}}-{\overline{\text { sector } \text { margin }_{i, p r e P E}}}_{)}\right. \\
& +\beta_{6}\left(\overline{\text { sales growth p.a. }}_{i_{i, \text { durPE}}}-\overline{\text { sales growth p.a. }}_{i, \mathrm{prePE}}\right)
\end{aligned}
$$

The panel consists only of two points in time for each cross-sectional unit $i$ : durPE captures the average of the margin pre PE, prePE the average of the margin during PE ownership

We use a weighted average of the sector margin, (total EBITDA divided by total sales of the sector) to handle the distortion coming from outliers in the sector figures, given that we have only 30-50 companies in each three digit sector. This is also the idea behind controlling for sector margin movements with a RHS variable instead of pooling the deals with sector companies.

The $P E$ dummy takes the value of 1 for all deals and represents therefore the intercept of the regression analog to alpha in the abnormal financial performance analysis. The PEduration dummy is defined as

\begin{tabular}{|c|c|c|c|c|c|c|}
\hline \multirow[t]{2}{*}{ Independent variables } & \multicolumn{6}{|c|}{ Dependent variable $\Delta$ EBITDA margin } \\
\hline & (1) & (2) & (3) & (4) & (5) & (6) \\
\hline \multirow[t]{2}{*}{$\mathbf{P E}$} & 1.23 & $3.96 * *$ & $3.97 * *$ & $3.85 * *$ & $3.85 * *$ & $4.13 * *$ \\
\hline & $(1.58)$ & $(2.14)$ & $(2.11)$ & $(2.02)$ & $(2.03)$ & $(2.12)$ \\
\hline \multirow[t]{2}{*}{ PE duration ${ }^{1}$} & & $-0.70 *$ & $-0.76^{* *}$ & $-0.70 *$ & $-0.70 *$ & $-0.73 * *$ \\
\hline & & $(-1.78)$ & $(-2.08)$ & $(-1.80)$ & $(-1.74)$ & $(-1.90)$ \\
\hline \multirow[t]{2}{*}{ Inorganic } & & & 0.47 & 0.46 & 0.46 & 0.46 \\
\hline & & & $(0.34)$ & $(0.33)$ & $(0.31)$ & $(0.32)$ \\
\hline \multirow[t]{2}{*}{ Bankruptcy } & & & & -1.37 & -1.37 & -0.97 \\
\hline & & & & $(-0.52)$ & $(-0.51)$ & $(-0.38)$ \\
\hline \multirow[t]{2}{*}{ Unexited } & & & & & -0.02 & 1.66 \\
\hline & & & & & $(-0.01)$ & $(0.99)$ \\
\hline \multirow[t]{2}{*}{$\Delta$ Sector margin } & $-0.66^{*}$ & $-0.71 * *$ & $-0.72 * *$ & $-0.76^{* *}$ & $-0.76^{* *}$ & $-0.84 * *$ \\
\hline & $(-1.90)$ & $(-2.27)$ & $(-2.20)$ & $(-2.26)$ & $(-2.14)$ & $(-2.43)$ \\
\hline $\begin{array}{l}\text { Sales growth p.a. above } \\
\text { sector }\end{array}$ & & & & & & $\begin{array}{l}-2.51 * \\
(-1.72)\end{array}$ \\
\hline Number of observations & \multicolumn{6}{|c|}{108} \\
\hline Number of deals & \multicolumn{6}{|c|}{54} \\
\hline $\mathrm{R}^{2}$ adjusted & 0.04 & 0.07 & 0.05 & 0.03 & 0.01 & 0.02 \\
\hline
\end{tabular}
the total number of PE ownership years. The dummies for bankruptcy, unexited or inorganic take the value of 1 if the argument is true during PE ownership.

Note: $\mathrm{t}$-stat in parenthesis with robust standard errors, significance level $* \mathrm{p}<0.1, * * \mathrm{p}<0.05, * * * \mathrm{p}<0.01$

1 The average duration for organic deals is 3.3 years, for inorganic 4.5 years 
Table 7 - Panel B: Analysis of PE impact on margin growth

The Table reports the estimated impact of PE in the same way as in Panel B, only focusing on changes in margin:

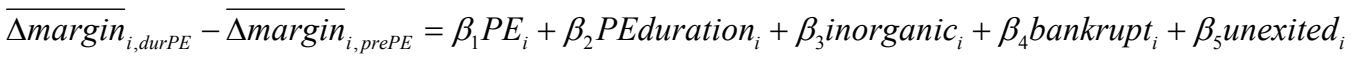

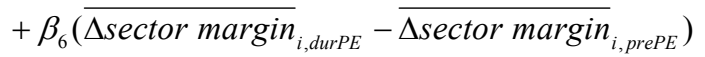

$$
\begin{aligned}
& +\beta_{6}\left(\overline{\text { sales growth p.a.above sector }}_{i, \text { durPE }}-\overline{\text { sales growth p.a. above sector }}_{i, \text { prePE }}\right)
\end{aligned}
$$

We use again two points in time for each cross-sectional unit $i$ : prePE captures the average percentage point change of the margin pre acquisition, $d u r P E$ the average of the percentage point change during PE ownership.

\begin{tabular}{|c|c|c|c|c|c|c|}
\hline \multirow[t]{2}{*}{ Independent variables } & \multicolumn{6}{|c|}{ Dependent variable $\Delta$ EBITDA margin ppt. change p.a. } \\
\hline & (1) & (2) & (3) & (4) & (5) & (6) \\
\hline \multirow[t]{2}{*}{ PE } & 0.70 & $2.97 * *$ & $3.04 * *$ & $3.06 * *$ & $3.17 * *$ & $3.22 * *$ \\
\hline & $(1.48)$ & $(2.04)$ & $(2.10)$ & $(2.06)$ & $(2.04)$ & $(2.16)$ \\
\hline \multirow[t]{2}{*}{ PE duration ${ }^{1}$} & & $-0.60 * *$ & $-0.46^{*}$ & -0.47 & $-0.53 *$ & $-0.54 *$ \\
\hline & & $(-2.08)$ & $(-1.74)$ & $(-1.68)$ & $(-1.70)$ & $(-1.76)$ \\
\hline \multirow[t]{2}{*}{ Inorganic } & & & $-1.29 *$ & $-1.28 *$ & $-1.20 *$ & $-1.16^{*}$ \\
\hline & & & $(-1.99)$ & $(-1.93)$ & $(-1.83)$ & $(-1.76)$ \\
\hline \multirow[t]{2}{*}{ Bankruptcy } & & & & 0.23 & 0.39 & 0.27 \\
\hline & & & & $(0.37)$ & $(0.60)$ & $(0.32)$ \\
\hline \multirow[t]{2}{*}{ Unexited } & & & & & 1.10 & 1.80 \\
\hline & & & & & $(0.90)$ & $(1.18)$ \\
\hline \multirow[t]{2}{*}{$\Delta$ Sector margin ppt change p.a. } & -0.16 & -0.07 & -0.03 & 0.03 & -0.09 & -0.27 \\
\hline & $(-0.64)$ & $(-0.33)$ & $(-0.13)$ & $(0.15)$ & $(-0.27)$ & $(-0.60)$ \\
\hline \multirow[t]{2}{*}{ Sales growth p.a. above sector } & & & & & & -3.95 \\
\hline & & & & & & $(-1.39)$ \\
\hline Number of observations & \multicolumn{6}{|c|}{76} \\
\hline Number of deals & \multicolumn{6}{|c|}{38} \\
\hline $\mathrm{R}^{2}$ adjusted & 0.01 & 0.14 & 0.17 & 0.14 & 0.12 & 0.16 \\
\hline
\end{tabular}

Note: $\mathrm{t}$-stats in parentheses with robust standard errors, significance level $* \mathrm{p}<0.1, * * \mathrm{p}<0.05, * * * \mathrm{p}<0.01$

1 The average duration for organic deals is 3.3 years, for inorganic 4.5 years 
Table 7 - Panel C: Analysis of PE impact on EBITDA multiple

The Table reports the impact of PE in on the EBITDA multiple:

multiple $_{i, \text { durPE }}-$ multiple $_{i, p r e P E}=\beta_{1} P E+\beta_{2} P E$ duration $+\beta_{3}$ inorganic $+\beta_{4}$ bankrupt $+\beta_{5}$ unexited $+\beta_{6}$ (sector multiple ${ }_{i, \text { durPE }}-$ sector multiple $_{i, \text { prePE }}$ )

We use two points in time for each cross-sectional unit $i$ : prePE captures the multiple at entry, durPE the multiple at exit.

The sector multiple is a weighted average (total EBITDA divided by total enterprise value of the sector) in order to handle the distortion coming from outliers in the sector figures, given that we have only 30-50 companies in each three digit sector. This is also the idea behind controlling for sector multiple movements with a RHS variable instead of pooling the deals with sector companies. We provide also regression with log multiple, to reduce the heteroscedasticity in our deal sample. Please note that sine we are using logs we can only include deals which had neither a negative EBITDA at entry nor at exit.

\begin{tabular}{|c|c|c|c|c|}
\hline & \multicolumn{4}{|c|}{ Dependent variable } \\
\hline \multirow[t]{2}{*}{ Independent variables } & \multicolumn{2}{|c|}{$\Delta$ EBITDA multiple } & \multicolumn{2}{|c|}{$\Delta \log$ EBITDA multiple ${ }^{2}$} \\
\hline & (1) & (2) & (3) & (4) \\
\hline \multirow[t]{2}{*}{$\mathbf{P E}$} & -0.81 & 0.13 & $0.42 * * *$ & $0.43 * * *$ \\
\hline & $(-0.20)$ & $(0.03)$ & $(2.95)$ & $(3.29)$ \\
\hline \multirow[t]{2}{*}{ PE duration ${ }^{1}$} & -0.23 & -0.69 & $-0.07 *$ & $-0.08 * *$ \\
\hline & $(-0.34)$ & $(-1.33)$ & $(-1.75)$ & $(-2.18)$ \\
\hline \multirow[t]{2}{*}{ Inorganic } & 5.29 & $5.83^{*}$ & 0.12 & 0.12 \\
\hline & $(1.64)$ & $(1.67)$ & $(0.90)$ & $(0.91)$ \\
\hline \multirow[t]{2}{*}{ Bankruptcy } & & 8.17 & & 0.10 \\
\hline & & $(1.12)$ & & $(0.18)$ \\
\hline \multirow[t]{2}{*}{ Unexited } & & 0.83 & & -0.10 \\
\hline & & $(0.33)$ & & $(-0.93)$ \\
\hline \multirow[t]{2}{*}{ Sector EBITDA multiple } & $0.08^{*}$ & 0.09 & & \\
\hline & $(1.85)$ & $(1.43)$ & & \\
\hline \multirow[t]{2}{*}{ Sector log EBITDA multiple } & & & -0.05 & -0.06 \\
\hline & & & $(-0.29)$ & $(-0.34)$ \\
\hline Number of observations & \multicolumn{2}{|c|}{122} & \multicolumn{2}{|c|}{118} \\
\hline Number of deals & \multicolumn{2}{|c|}{61} & \multicolumn{2}{|c|}{59} \\
\hline $\mathrm{R}^{2}$ adjusted & -0.03 & -0.04 & 0.13 & 0.10 \\
\hline
\end{tabular}

Note: $t$-stats in parentheses with robust standard errors, significance level $* \mathrm{p}<0.1, * * \mathrm{p}<0.05, * * * \mathrm{p}<0.01$

1 The average duration for organic deals is 3.3 years, for inorganic 4.5 years

2 Excluding 2 deals, which have a negative EBITDA 
Table 8: Explaining cross-sectional variation in alpha with operational improvements ${ }^{1}$

\begin{tabular}{|c|c|c|c|c|c|}
\hline \multirow[t]{2}{*}{ Independent variables } & \multicolumn{5}{|c|}{ Alpha in percent } \\
\hline & (1) & (2) & (3) & (4) & $(5)^{3}$ \\
\hline PE duration ${ }^{2}$ & $-6.58 * * *$ & $-4.47 * * *$ & $-5.57 * *$ & $-3.29 * *$ & -2.46 \\
\hline (total \# of PE years until exit) & $(-3.05)$ & $(-3.16)$ & $(-2.14)$ & $(-2.28)$ & $(-1.19)$ \\
\hline $\begin{array}{l}\text { Inorganic dummy } \\
\text { (1 if } \mathrm{M} / \mathrm{A} \text { until exit) }\end{array}$ & $\begin{array}{l}-2.53 \\
(-0.53)\end{array}$ & $\begin{array}{l}-5.08 \\
(-1.27)\end{array}$ & $\begin{array}{l}-4.64 \\
(-1.09)\end{array}$ & $\begin{array}{l}-6.90 * \\
(-1.72)\end{array}$ & $\begin{array}{l}-1.91 \\
(-0.35)\end{array}$ \\
\hline $\begin{array}{l}\text { Unexited dummy } \\
\text { (1 if not exited until 2008) }\end{array}$ & $\begin{array}{l}5.18 \\
(0.55)\end{array}$ & $\begin{array}{l}-2.17 \\
(-0.31)\end{array}$ & $\begin{array}{l}2.91 \\
(0.30)\end{array}$ & $\begin{array}{l}-3.98 \\
(-0.49)\end{array}$ & $\begin{array}{l}-5.48 \\
(-0.73)\end{array}$ \\
\hline $\begin{array}{l}\text { Bankruptcy dummy } \\
\text { (1 if bankruptcy during PE) }\end{array}$ & & $\begin{array}{l}-41.63 * * * \\
(-8.98)\end{array}$ & & $\begin{array}{l}-41.35 * * * \\
(-6.76)\end{array}$ & $\begin{array}{l}-42.73 * * * \\
(-4.65)\end{array}$ \\
\hline $\begin{array}{l}\text { Margin increase above sector } \\
\text { (percentage points p.a. relative to entry) }\end{array}$ & $\begin{array}{l}0.50 \\
(1.41) \\
\end{array}$ & $\begin{array}{l}0.58^{*} \\
(1.84) \\
\end{array}$ & $\begin{array}{l}0.74 \\
(1.51) \\
\end{array}$ & $\begin{array}{l}1.01 * * \\
(2.51)\end{array}$ & \\
\hline $\begin{array}{l}\text { Margin growth change above sector } \\
\text { (percentage points p.a. relative to entry) }\end{array}$ & & & & & $\begin{array}{l}2.21 * \\
(1.86)\end{array}$ \\
\hline $\begin{array}{l}\text { Sales growth above sector } \\
\text { (percent p.a.) }\end{array}$ & $\begin{array}{l}-14.42 \\
(-1.25)\end{array}$ & $\begin{array}{l}1.38 \\
(0.16)\end{array}$ & $\begin{array}{l}-7.46 \\
(-0.63)\end{array}$ & $\begin{array}{l}9.94 \\
(0.99)\end{array}$ & $\begin{array}{l}0.28 \\
(1.63)\end{array}$ \\
\hline Multiple increase above sector & $\begin{array}{l}0.19 \\
(1.27)\end{array}$ & $\begin{array}{l}0.20 * \\
(1.77)\end{array}$ & & & \\
\hline Log multiple increase above sector & & & $\begin{array}{l}9.16 \\
(1.30)\end{array}$ & $\begin{array}{l}10.30 * * \\
(2.56)\end{array}$ & $\begin{array}{l}10.47^{*} \\
(2.01)\end{array}$ \\
\hline $\begin{array}{l}\text { Entry dummy 96-00 } \\
(1996-2000)\end{array}$ & $\begin{array}{l}16.36^{* * * *} \\
(3.11)\end{array}$ & $\begin{array}{l}17.32 * * * \\
(3.50)\end{array}$ & $\begin{array}{l}14.99 * * * \\
(2.91)\end{array}$ & $\begin{array}{l}16.16^{* * *} \\
(3.41)\end{array}$ & $\begin{array}{l}9.09 \\
(1.18)\end{array}$ \\
\hline $\begin{array}{l}\text { Entry dummy 01-02 } \\
(2001-2002)\end{array}$ & $\begin{array}{l}17.62 * * \\
(2.61)\end{array}$ & $\begin{array}{l}17.08 * * \\
(2.42)\end{array}$ & $\begin{array}{l}16.09 * * \\
(2.48)\end{array}$ & $\begin{array}{l}16.00 * * \\
(2.35)\end{array}$ & $\begin{array}{l}11.08 \\
(1.59)\end{array}$ \\
\hline $\begin{array}{l}\text { Size } \\
\left(\text { Entry value* } 10^{\wedge} 5\right)\end{array}$ & $\begin{array}{l}-0.00 \\
(-0.39)\end{array}$ & $\begin{array}{l}-0.00 \\
(-0.68)\end{array}$ & $\begin{array}{l}-0.00 \\
(-0.42)\end{array}$ & $\begin{array}{l}-0.00 \\
(-0.74)\end{array}$ & $\begin{array}{l}-0.00 \\
(-0.73)\end{array}$ \\
\hline Intercept & $\begin{array}{l}23.32 * * * \\
(2.94)\end{array}$ & $\begin{array}{l}18.70 * * * \\
(2.83)\end{array}$ & $\begin{array}{l}20.73 * * \\
(2.19) \\
\end{array}$ & $\begin{array}{l}14.85 * * \\
(2.28) \\
\end{array}$ & $\begin{array}{l}7.65 \\
(0.92) \\
\end{array}$ \\
\hline Number of observations (deals) & 52 & 52 & 50 & 50 & 37 \\
\hline $\mathrm{R}^{2}$ adjusted & 0.31 & 0.52 & 0.34 & 0.55 & 0.52 \\
\hline
\end{tabular}

Note: $t$-stats in parentheses with robust standard errors, significance level $* \mathrm{p}<0.1, * * \mathrm{p}<0.05, * * * \mathrm{p}<0.01$

1 Deals are only included if sales and EBITDA PRE and during PE ownership are available

2 The average duration for organic deals is 3.3 years, for inorganic 4.5 years

3 Deals only included if at least two years of data before PE ownership are available 
Table 9: PE vs. PLC governance models

\begin{tabular}{|c|c|c|}
\hline & PE Model & PLC Model \\
\hline $\begin{array}{l}\text { 1. Change in senior } \\
\text { management }\end{array}$ & $\begin{array}{l}\text { - CEO changed in } 69 \% \text { of deals (and } \\
\text { within } 1^{\text {st }} 100 \text { days in } 39 \% \text { deals) }\end{array}$ & $\begin{array}{l}\text { - Average CEO service }= \\
4.7 \text { years }\end{array}$ \\
\hline 2. Cost focus & $\begin{array}{l}\text { - Successful deals grow margins as } \\
\text { well as sales by cutting costs and } \\
\text { increasing efficiency }\end{array}$ & $\begin{array}{l}\text { Only } 36 \% \text { of boards } \\
\text { rates themselves as } \\
\text { good at cost reduction }\end{array}$ \\
\hline $\begin{array}{l}\text { 3. Frequency of board } \\
\text { meetings }\end{array}$ & $\begin{array}{l}\text { - Formal - 9/year on average } \\
\text { - Informal - c. } 90 \% \text { of deals involve } \\
\text { contact between GP and CEO at least } \\
\text { once/week throughout deal life (with } \\
\text { many deals involving frequent contact } \\
\text { every day) }\end{array}$ & - Formal - 9/year \\
\hline 4. Time commitment to firm & $\begin{array}{l}\text { - PE partners }-0.4 \text { Partner FTEs in } 1^{\text {st }} \\
100 \text { days }\end{array}$ & $\begin{array}{l}\text { - } 20 \text { hours a month } \\
\text { equating to } 0.1 \text { FTE } \\
\text { (based on } 240 \text { working } \\
\text { days/year and } 10 \text { hours/ } \\
\text { working day }\end{array}$ \\
\hline 5. Ownership of firm & $\begin{array}{l}\text { PE owns } 75 \% \text { of total deal equity } \\
\text { (inc. equity owned by other club } \\
\text { members) and 'votes } 100 \% \text { of shares' }\end{array}$ & $\begin{array}{l}\text { - NXD have little equity } \\
\text { and own less than } 2 \text { of } \\
\text { voting rights } \\
\text { - Salary } £ 40-60 \mathrm{k}\end{array}$ \\
\hline $\begin{array}{l}\text { 6. Management investment in } \\
\text { deal }\end{array}$ & $\begin{array}{l}\text { - Managements co-invests and owns } \\
\sim 15 \% \text { of ordinary equity } \\
\text { - CEO co-invests and owns } \sim 6 \%\end{array}$ & $\begin{array}{l}\text { - CEO does not co- } \\
\text { invest; works on salary } \\
\text { and stock options }\end{array}$ \\
\hline 7. Average board size & - 8 members & - 10 members \\
\hline 8. Board composition & $\begin{array}{ll}\text { - } & \mathrm{NXD}=24 \% \\
\text { - } & \mathrm{PE}=23 \% \\
\text { - } & \mathrm{Mgt}=43 \%\end{array}$ & $\begin{array}{l}\text { - } \mathrm{NXD}=50 \% \\
\text { - } \mathrm{PE}=0 \%(\mathrm{n} / \mathrm{a}) \\
\text { - } \mathrm{Mgt}=50 \%\end{array}$ \\
\hline
\end{tabular}

Source of PLC data: Spencer Stuart 2005 board Index for top 150 firms in the UK (matched to average size of sample deals); Korn Ferry 33rd Annual Board of Directors Study. 
Table 10: PE follows an active governance approach

\begin{tabular}{|c|c|c|c|c|}
\hline 1. Management changes $(n=51)$ & $1^{\text {st }} 100$ days & \multicolumn{3}{|l|}{ Overall } \\
\hline - Replacing CEO & 39 & \multicolumn{3}{|l|}{69} \\
\hline - Replacing CFO & 33 & \multicolumn{3}{|l|}{61} \\
\hline 2. Value creation initiatives $(n=50)$ & Organic growth & Productivity & \multicolumn{2}{|c|}{ Strategic reposition. } \\
\hline - $1^{\text {st }} 100$ days & 60 & 54 & \multicolumn{2}{|l|}{26} \\
\hline \multicolumn{5}{|l|}{ 3. Value creation plan adj. $(n=44)$} \\
\hline $\begin{array}{l}\text { Actively shaped plan ( } \% \text { of deals } \\
\text { where value plan was revised) }\end{array}$ & Overhaul plan & Minor changes & \multicolumn{2}{|l|}{ No changes } \\
\hline - Pre-close & 30 & 19 & \multirow{2}{*}{\multicolumn{2}{|c|}{$\begin{array}{l}28 \\
63\end{array}$}} \\
\hline - $1^{\text {st }} 100$ days & 4 & 11 & & \\
\hline \multicolumn{5}{|l|}{ 4. Management support $(n=48)$} \\
\hline $\begin{array}{l}\text { Significant time commitment by PE } \\
\text { firm }\end{array}$ & DD & $1^{\text {st }} 100$ days & Rest of Y 1 & Year 2 \\
\hline - Total FTEs & 2.96 & 0.73 & 0.41 & 0.41 \\
\hline - Partner FTEs & 1.44 & 0.41 & 0.25 & 0.43 \\
\hline Regular interaction with board & Monthly & Quarterly & \multicolumn{2}{|l|}{$>3$ month } \\
\hline - Board meetings (split in \%) & 68 & 19 & \multicolumn{2}{|l|}{13} \\
\hline $\begin{array}{l}\text { Informal regular interactions with } \\
\mathrm{CEO}\end{array}$ & >once a week & Once a week & \multicolumn{2}{|l|}{ Infrequently } \\
\hline - In $1^{\text {st }} 100$ days & 52 & 40 & \multicolumn{2}{|l|}{8} \\
\hline 5. Strong incentives $(n=54)$ & Share of equity & \multicolumn{3}{|l|}{ of total equity } \\
\hline - Management team & 14.6 & \multirow{2}{*}{\multicolumn{3}{|c|}{$\begin{array}{l}3.0 \\
1.2\end{array}$}} \\
\hline - Of which CEO & 5.7 & & & \\
\hline 6. Effective board $(n=52)$ & PE staff & Mgt. team & NXDS & Total \\
\hline - Average staff & 2.5 & 3.3 & 1.9 & 7.7 \\
\hline - Board composition (split in \%) & 33 & 43 & 24 & 100 \\
\hline 7. External support $(n=46)$ & DD & $1^{\text {st }} 100$ days & \multicolumn{2}{|c|}{ After $1^{\text {st }} 100$ days } \\
\hline - Deals with external expertise & 78 & 29 & \multicolumn{2}{|l|}{22} \\
\hline
\end{tabular}

Note: All values in percent (percent of deals, which took the action) 
Table 11 - Panel A: Construction of active governance score

\begin{tabular}{|c|c|c|}
\hline Deal involvement & Each action scores 100 & Scores 0 \\
\hline $\begin{array}{l}\text { 1. Management changes in } \\
1^{\text {st }} 100 \text { days or before }\end{array}$ & $\begin{array}{l}\text { - Replacing CEO } \\
\text { - Replacing CFO } \\
\text { - Replacing Other }\end{array}$ & $\begin{array}{l}\text { All other } \\
\text { outcomes }\end{array}$ \\
\hline $\begin{array}{l}\text { 2. Value creation initiatives } \\
\text { in } 1^{\text {st }} 100 \text { days }\end{array}$ & $\begin{array}{l}\text { - } \text { Organic growth } \\
\text { - } \\
\text { - } \text { Productivity }^{2} \\
\text { - } \text { Strategic repositioning }\end{array}$ & $\begin{array}{l}\text { All other } \\
\text { outcomes }\end{array}$ \\
\hline $\begin{array}{l}\text { 3. Value creation plan } \\
\text { adjustments }\end{array}$ & $\begin{array}{l}\text { - Revised mngmt. plan in } 1 \text { st } 100 \text { days } \\
\text { - Introduced new Key Performance Indicators (KPIs) } \\
\text { in } 1 \text { st } 100 \text { days } \\
\text { - Acted on deviations immediately during any period }\end{array}$ & $\begin{array}{l}\text { All other } \\
\text { outcomes }\end{array}$ \\
\hline 4. Management support & $\begin{array}{l}\text { - Multiple CEO interactions per week } \\
\text { - Frequent CFO interactions during deal } \\
\text { - Committing GP time above cross-sectional average }\end{array}$ & $\begin{array}{l}\text { All other } \\
\text { outcomes }\end{array}$ \\
\hline 5. Strong incentives & $\begin{array}{l}\text { - Mngmt. equity above cross-sectional average } \\
\text { - } \mathrm{CEO}, 1 \text { st line } \& \text { 2nd line with equity } \\
\text { - Management above average cash multiple }\end{array}$ & $\begin{array}{l}\text { All other } \\
\text { outcomes }\end{array}$ \\
\hline 6. Effective board & $\begin{array}{l}\text { - Board size below cross-sectional average } \\
\text { - Percentage of NXDs below average } \\
\text { - CEO and Chairman different }\end{array}$ & $\begin{array}{l}\text { All other } \\
\text { outcomes }\end{array}$ \\
\hline 7. External support & $\begin{array}{l}\text { - Used in Due Diligence (DD) } \\
\text { - Used in } 1 \text { st } 100 \text { days } \\
\text { - Used after } 1 \text { st } 100 \text { days }\end{array}$ & $\begin{array}{l}\text { All other } \\
\text { outcomes }\end{array}$ \\
\hline
\end{tabular}

1 Organic growth initiatives are 1) review of pricing, 2) new channels, 3) new products, 4) new geographies 5) existing geographies, new customers, 6) existing geographies, existing customers

2 Productivity initiatives are 1) purchasing (e.g., supplier consolidation), 2) process efficiency (e.g., supply chain), 3) overhead reduction (e.g., SG\&A, or Selling, General and Admin costs), 4) other cost reduction (detailed by interview), 5) working capital reduction, 6) CAPEX reduction 
Table 11 - Panel B: PE involvement and abnormal financial performance

\begin{tabular}{|c|c|c|c|c|}
\hline $\begin{array}{l}\text { Deal } \\
\text { involvement }\end{array}$ & Action taken & $\begin{array}{l}\text { Mean } \\
\text { score all } \\
\text { deals }\end{array}$ & $\begin{array}{l}\text { Mean score } \\
\text { top alpha } \\
\text { tercile }\end{array}$ & $\begin{array}{l}\text { t-stat of } \\
\text { dif. }\end{array}$ \\
\hline \multirow{4}{*}{$\begin{array}{l}\text { 1. Management } \\
\text { changes in } 1^{\text {st }} \\
100 \text { days or } \\
\text { before }\end{array}$} & Replacing CEO & 40 & 50 & 0.6 \\
\hline & Replacing CFO & 36 & 42 & 0.4 \\
\hline & Replacing Other & 34 & 42 & 0.5 \\
\hline & Subtotal $^{2}$ & 37 & 49 & 1.0 \\
\hline \multirow{4}{*}{$\begin{array}{l}\text { 2. Value creation } \\
\text { initiatives in } 1^{\text {st }} \\
100 \text { days }\end{array}$} & Organic growth & 71 & 69 & -0.1 \\
\hline & Productivity & 62 & 62 & 0.0 \\
\hline & Strategic repositioning & 44 & 54 & 0.7 \\
\hline & Subtotal $^{2}$ & 59 & 62 & 0.4 \\
\hline \multirow{4}{*}{$\begin{array}{l}\text { 3. Value creation } \\
\text { plan } \\
\text { adjustments }\end{array}$} & Revised mngmt. plan in 1 st 100 days & 73 & 85 & 1.1 \\
\hline & Introduced new KPIs in 1st 100 days & 71 & 75 & 0.3 \\
\hline & Acted on deviations & 53 & 35 & -1.5 \\
\hline & Subtotal $^{2}$ & 66 & 68 & 0.2 \\
\hline \multirow{4}{*}{$\begin{array}{l}\text { 4. Management } \\
\text { support }\end{array}$} & Mult. CEO interactions /week & 54 & 92 & $4.5^{* * *}$ \\
\hline & Frequent CFO interactions & 98 & 100 & $* * *$ \\
\hline & Committing GP time above ${ }^{3}$ & 50 & 62 & 0.8 \\
\hline & Subtotal $^{2}$ & 67 & 77 & $2.2 * * *$ \\
\hline \multirow{4}{*}{$\begin{array}{l}\text { 5. Strong } \\
\text { incentives }\end{array}$} & Mngmt. equity above ${ }^{3}$ & 54 & 46 & -0.6 \\
\hline & Mngmt. with equity & 71 & 83 & 1.1 \\
\hline & Mngmt. cash-multiple above ${ }^{3}$ & 75 & 46 & $-2.0^{*}$ \\
\hline & Subtotal $^{2}$ & 67 & 43 & $-2.4 * *$ \\
\hline \multirow{4}{*}{$\begin{array}{l}\text { 6. Effective } \\
\text { board }\end{array}$} & Board size below ${ }^{3}$ & 58 & 38 & -1.4 \\
\hline & Percentage of NXDs below ${ }^{3}$ & 50 & 62 & 0.8 \\
\hline & CEO and Chairman different & 89 & 83 & -0.5 \\
\hline & Subtotal $^{2}$ & 66 & 68 & 0.2 \\
\hline \multirow{4}{*}{$\begin{array}{l}\text { 7. External } \\
\text { support }\end{array}$} & Used in DD & 74 & 92 & $2.1 * *$ \\
\hline & Used in 1 st 100 days & 36 & 75 & $3.0 * * *$ \\
\hline & Used after 1 st 100 days & 40 & 50 & 0.6 \\
\hline & Subtotal $^{2}$ & 50 & 71 & $2.6^{* *}$ \\
\hline \multicolumn{2}{|l|}{ Grand total $^{2}$} & 59 & 63 & 1.3 \\
\hline \multicolumn{2}{|l|}{$\mathbf{N}$} & 48 & 13 & 13 \\
\hline
\end{tabular}

Note: All values in percent (percent of deals, which answered yes)

1 Deals sorted by Alpha, the column represents the mean score for the top alpha tercile

2 Blank interview answers (13.7\% of all answers) in one of the three answers of the 7 deal involvement types are filled with the cross sectional average per question

3 Cross-sectional averages of all deals 
Table 11 -Panel C: Alpha and Governance Scores

\begin{tabular}{|c|c|c|c|c|c|c|c|c|c|}
\hline \multirow{2}{*}{$\begin{array}{l}\text { Independe } \\
\text { nt } \\
\text { variables }\end{array}$} & \multicolumn{9}{|c|}{ Dependent variable alpha in percent ${ }^{1}$} \\
\hline & (1) & (2) & (3) & (4) & (5) & (6) & (7) & (8) & (9) \\
\hline $\begin{array}{l}\text { PE } \\
\text { duration }\end{array}$ & $\begin{array}{l}-7.74 * * * \\
(-3.51)\end{array}$ & $\begin{array}{l}-8.44 * * * \\
(-3.67)\end{array}$ & $\begin{array}{l}-8.32 * * * \\
(-3.72)\end{array}$ & $\begin{array}{l}-8.16^{* * *} \\
(-3.50)\end{array}$ & $\begin{array}{l}-8.29 * * * \\
(-3.62)\end{array}$ & $\begin{array}{l}-8.47 * * * \\
(-3.81)\end{array}$ & $\begin{array}{l}-9.07 * * * \\
(-4.47)\end{array}$ & $\begin{array}{l}-8.88 * * * \\
(-4.37)\end{array}$ & $\begin{array}{l}-7.00 * * * \\
(-3.23)\end{array}$ \\
\hline $\begin{array}{l}\text { Inorganic } \\
\text { dummy }\end{array}$ & $\begin{array}{l}-9.97 * \\
(-1.98) \\
\end{array}$ & $\begin{array}{l}-8.91 * \\
(-1.75) \\
\end{array}$ & $\begin{array}{l}-8.82 * \\
(-1.99) \\
\end{array}$ & $\begin{array}{l}-8.71 * \\
(-2.00) \\
\end{array}$ & $\begin{array}{l}-8.91 * \\
(-1.88) \\
\end{array}$ & $\begin{array}{l}-9.04 * * \\
(-2.03)\end{array}$ & $\begin{array}{l}-5.98 \\
(-1.38) \\
\end{array}$ & $\begin{array}{l}-5.98 \\
(-1.47) \\
\end{array}$ & $\begin{array}{l}-8.45^{*} \\
(-1.85) \\
\end{array}$ \\
\hline $\begin{array}{l}\text { Unexited } \\
\text { dummy }\end{array}$ & $\begin{array}{l}16.43^{* *} \\
(2.02)\end{array}$ & $\begin{array}{l}16.35^{*} \\
(1.96) \\
\end{array}$ & $\begin{array}{l}16.11^{*} \\
(1.99) \\
\end{array}$ & $\begin{array}{l}19.19^{* *} \\
(2.48)\end{array}$ & $\begin{array}{l}16.53 * * \\
(2.12)\end{array}$ & $\begin{array}{l}16.04 * \\
(1.97) \\
\end{array}$ & $\begin{array}{l}13.79 * * \\
(2.21)\end{array}$ & $\begin{array}{l}15.99 * * \\
(2.69)\end{array}$ & $\begin{array}{l}15.79 * * * \\
(2.83)\end{array}$ \\
\hline $\begin{array}{l}\text { Entry } \\
96-00\end{array}$ & $\begin{array}{l}22.97 * * \\
(2.99)\end{array}$ & $\begin{array}{l}23.96 * * * \\
(3.06)\end{array}$ & $\begin{array}{l}23.77 * * * \\
(3.04)\end{array}$ & $\begin{array}{l}27.72 * * * \\
(3.93)\end{array}$ & $\begin{array}{l}23.70 * * * \\
(2.96)\end{array}$ & $\begin{array}{l}24.10^{* * *} \\
(3.15)\end{array}$ & $\begin{array}{l}27.24 * * * \\
(4.15)\end{array}$ & $\begin{array}{l}29.30 * * * \\
(4.88)\end{array}$ & $\begin{array}{l}28.71 * * * \\
(5.32)\end{array}$ \\
\hline $\begin{array}{l}\text { Entry } \\
01-02\end{array}$ & $\begin{array}{l}15.28 * \\
(2.01) \\
\end{array}$ & $\begin{array}{l}14.78^{*} \\
(1.93)\end{array}$ & $\begin{array}{l}15.02 * \\
(1.96)\end{array}$ & $\begin{array}{l}13.85^{* *} \\
(2.03)\end{array}$ & $\begin{array}{l}14.93 * \\
(1.96)\end{array}$ & $\begin{array}{l}14.98 * \\
(1.96)\end{array}$ & $\begin{array}{l}10.63 * \\
(1.97)\end{array}$ & $\begin{array}{l}10.37 * \\
(2.01)\end{array}$ & $\begin{array}{l}12.01 * * \\
(2.28)\end{array}$ \\
\hline Size & $\begin{array}{l}-0.00 \\
(-0.35) \\
\end{array}$ & $\begin{array}{l}-0.00 \\
(-0.33) \\
\end{array}$ & $\begin{array}{l}-0.00 \\
(-0.37) \\
\end{array}$ & $\begin{array}{l}-0.00 \\
(-0.90) \\
\end{array}$ & $\begin{array}{l}-0.00 \\
(-0.39) \\
\end{array}$ & $\begin{array}{l}-0.00 \\
(-0.36)\end{array}$ & $\begin{array}{l}-0.00 \\
(-0.19)\end{array}$ & $\begin{array}{l}-0.00 \\
(-0.60)\end{array}$ & $\begin{array}{l}-0.00 \\
(-0.88) \\
\end{array}$ \\
\hline Intercept & $\begin{array}{l}23.64 * * \\
(2.29)\end{array}$ & $\begin{array}{l}27.42 * * \\
(2.46)\end{array}$ & $\begin{array}{l}24.81 * * \\
(2.10)\end{array}$ & $\begin{array}{l}11.30 \\
(1.02) \\
\end{array}$ & $\begin{array}{l}33.00 * * * \\
(2.74)\end{array}$ & $\begin{array}{l}30.81 * * \\
(2.46)\end{array}$ & $\begin{array}{l}15.24 \\
(1.63) \\
\end{array}$ & $\begin{array}{l}6.10 \\
(0.62) \\
\end{array}$ & $\begin{array}{l}8.98 \\
(0.61) \\
\end{array}$ \\
\hline $\begin{array}{l}\text { 1. Mngmt. } \\
\text { changes }\end{array}$ & $\begin{array}{l}6.59 \\
(1.35) \\
\end{array}$ & & & & & & & & $\begin{array}{l}13.91^{* *} \\
(2.09)\end{array}$ \\
\hline $\begin{array}{l}\text { 2. Value } \\
\text { creation } \\
\text { initiatives }\end{array}$ & & $\begin{array}{l}1.76 \\
(0.24)\end{array}$ & & & & & & & $\begin{array}{l}-13.45 \\
-13.45\end{array}$ \\
\hline $\begin{array}{l}\text { 3. Value } \\
\text { creation } \\
\text { plan adj. }\end{array}$ & & & $\begin{array}{l}4.96 \\
(0.56)\end{array}$ & & & & & & $\begin{array}{l}-8.98 \\
(-1.07)\end{array}$ \\
\hline $\begin{array}{l}\text { 4. Mngmt. } \\
\text { support }\end{array}$ & & & & $\begin{array}{l}23.17 * * \\
(2.41)\end{array}$ & & & & $\begin{array}{l}14.43^{*} \\
(1.74)\end{array}$ & $\begin{array}{l}23.66 * * \\
23.66^{* *}\end{array}$ \\
\hline $\begin{array}{l}\text { 5. Strong } \\
\text { incentives }\end{array}$ & & & & & $\begin{array}{l}-7.48 \\
(-0.66) \\
\end{array}$ & & & & $\begin{array}{l}-5.41 \\
(-0.50) \\
\end{array}$ \\
\hline $\begin{array}{l}\text { 6. Eff. } \\
\text { board }\end{array}$ & & & & & & $\begin{array}{l}-3.33 \\
(-0.40)\end{array}$ & & & $\begin{array}{l}-5.62 \\
(-0.80)\end{array}$ \\
\hline $\begin{array}{l}\text { 7. Ext. } \\
\text { support }\end{array}$ & & & & & & & $\begin{array}{l}27.28 * * * \\
(4.04)\end{array}$ & $\begin{array}{l}24.36^{* * * *} \\
(3.71)\end{array}$ & $\begin{array}{l}25.88^{* * *} \\
(3.94)\end{array}$ \\
\hline $\mathbf{N}$ & 48 & 48 & 48 & 48 & 48 & 48 & 48 & 48 & 48 \\
\hline $\mathrm{R}^{2}$ adjusted & 0.33 & 0.31 & 0.31 & 0.38 & 0.32 & 31 & 0.50 & 0.51 & 0.54 \\
\hline
\end{tabular}

Note: $t$-stat in parenthesis, significance level $* \mathrm{p}<0.1, * * \mathrm{p}<0.05, * * * \mathrm{p}<0.01$

1 To derive totals per sub question, blank interview answers (13.7\% of all answers) in one of the three answers of each of the 7 deal involvement types are filled with the cross sectional average of all deals 
Table 12 - Panel A: Univariate tests: operational improvements and active governance scores

\begin{tabular}{|c|c|c|c|c|c|c|}
\hline \multirow{2}{*}{$\begin{array}{l}\text { Deal } \\
\text { involvement }\end{array}$} & \multirow[t]{2}{*}{ Action taken } & \multicolumn{3}{|c|}{ Mean score } & \multicolumn{2}{|c|}{ t-stat of dif. } \\
\hline & & $\begin{array}{l}\text { all } \\
\text { deals }\end{array}$ & $\begin{array}{l}\text { all } \\
\text { organic } \\
\text { deals }\end{array}$ & $\begin{array}{l}\text { margin } \\
\text { increase } \\
\text { above } \\
\text { sector }\end{array}$ & $\begin{array}{l}\text { margin } \\
\text { increase } \\
\text { vs. all } \\
\text { deals }\end{array}$ & $\begin{array}{l}\text { margin } \\
\text { increase } \\
\text { vs. } \\
\text { organic }\end{array}$ \\
\hline \multirow{4}{*}{$\begin{array}{l}\text { 1. Mngmnt. } \\
\text { changes in } \\
1^{\text {st }} 100 \text { days } \\
\text { or before }\end{array}$} & Replacing CEO & 40 & 41 & 75 & $2.1^{*}$ & $2.1^{*}$ \\
\hline & Replacing CFO & 36 & 35 & 63 & 1.4 & 1.5 \\
\hline & Replacing Other & 34 & 35 & 63 & 1.6 & 1.5 \\
\hline & Subtotal $^{1}$ & 37 & 40 & 67 & $1.9 *$ & 1.7 \\
\hline \multirow{4}{*}{$\begin{array}{l}\text { 2. Value } \\
\text { creation } \\
\text { initiatives } \\
\text { in } 1^{\text {st }} 100 \\
\text { days }\end{array}$} & Organic growth & 71 & 69 & 63 & -0.5 & -0.8 \\
\hline & Productivity & 62 & 67 & 100 & $* * *$ & $* * *$ \\
\hline & Strategic repositioning & 44 & 53 & 38 & -0.4 & -0.3 \\
\hline & Subtotal $^{1}$ & 59 & 67 & 67 & 1.2 & -0.2 \\
\hline \multirow{4}{*}{$\begin{array}{l}\text { 3. Value } \\
\text { creation } \\
\text { plan } \\
\text { adjustments }\end{array}$} & Revised mngmt. plan ${ }^{2}$ & 73 & 71 & 87 & 1.1 & 1.3 \\
\hline & Introduced new KPIs ${ }^{2}$ & 71 & 78 & 84 & 1.0 & 0.5 \\
\hline & Acted on deviations & 53 & 35 & 83 & 1.7 & $2.9 * *$ \\
\hline & Subtotal $^{1}$ & 66 & 70 & 82 & $2.1^{*}$ & 0.7 \\
\hline \multirow{4}{*}{$\begin{array}{l}\text { 4. Mngmt. } \\
\text { support }\end{array}$} & Mult. CEO interactions /week & 55 & 59 & 71 & 0.9 & 0.7 \\
\hline & Frequent $\mathrm{CFO}$ interactions & 98 & 98 & 100 & $* * *$ & $* * *$ \\
\hline & Committing GP time above ${ }^{3}$ & 50 & 45 & 38 & 0.7 & -0.4 \\
\hline & Subtotal $^{1}$ & 67 & 72 & 75 & 0.9 & 0.4 \\
\hline \multirow{4}{*}{$\begin{array}{l}\text { 5. Strong } \\
\text { incentives }\end{array}$} & Mngmt. equity above ${ }^{3}$ & 54 & 47 & 38 & -0.9 & -0.5 \\
\hline & Mngmt. with equity & 71 & 67 & 67 & -0.2 & 0.0 \\
\hline & Mngmt. cash-multiple above ${ }^{3}$ & 75 & 50 & 52 & -0.7 & 0.7 \\
\hline & Subtotal $^{1}$ & 67 & 45 & 67 & $\mathbf{0 . 0}$ & 0.2 \\
\hline \multirow{4}{*}{$\begin{array}{l}\text { 6. Effective } \\
\text { board }\end{array}$} & Board size below ${ }^{3}$ & 58 & 58 & 62 & 0.2 & 0.2 \\
\hline & Percentage of NXDs below ${ }^{3}$ & 50 & 50 & 50 & 0.0 & -0.2 \\
\hline & CEO and Chairman different & 89 & 93 & 100 & $* * *$ & $* * *$ \\
\hline & Subtotal $^{1}$ & 66 & 59 & 70 & 0.6 & $2.1 *$ \\
\hline \multirow{4}{*}{$\begin{array}{l}\text { 7. External } \\
\text { support }\end{array}$} & Used in DD & 74 & 75 & 100 &.$^{* * *}$ & $* * *$ \\
\hline & Used in 1 st 100 days & 36 & 47 & 57 & 1.1 & 0.5 \\
\hline & Used after 1st 100 days & 40 & 41 & 57 & 0.8 & 0.8 \\
\hline & Subtotal $^{1}$ & 50 & 57 & 69 & $2.3 * *$ & 1.7 \\
\hline \multicolumn{2}{|l|}{ Grand total $^{1}$} & 59 & 62 & 68 & $2.1 *$ & 1.4 \\
\hline \multicolumn{2}{|l|}{$\mathbf{N}$} & 48 & 26 & 8 & 8 & 8 \\
\hline \multicolumn{7}{|c|}{ Note: All values in percent (percent of deals, which answered yes) } \\
\hline \multicolumn{7}{|c|}{$\begin{array}{l}1 \text { To derive totals per sub question, blank interview answers ( } 13.7 \% \text { of all answers) in one of the three answers of each of the } 7 \\
\text { deal involvement types are filled with the cross sectional average of all deals. }\end{array}$} \\
\hline \multicolumn{7}{|l|}{2 In 1st 100 days } \\
\hline \multicolumn{7}{|c|}{3 Cross-sectional average of all deals } \\
\hline \multicolumn{7}{|c|}{4 Organic deals only } \\
\hline
\end{tabular}


Table 12 - Panel B: Productivity \& organic growth initiatives and operational improvements

\begin{tabular}{ll|l|l}
\hline \hline $\begin{array}{l}\text { value creation } \\
\text { initiative }\end{array}$ & sub-initiative & $\begin{array}{l}\text { margin increase } \\
\text { above sector }^{1}\end{array}$ & $\begin{array}{l}\text { margin increase } \\
\text { below sector }^{2}\end{array}$ \\
\hline $\begin{array}{l}\text { Productivity } \\
\text { (before and } \\
\text { during first 100 } \\
\text { days) }\end{array}$ & Purchasing (e.g., supplier consolidation) & 43 & 22 \\
& Orocess efficiency (e.g., supply chain) & 29 & 33 \\
& Ooverhead reduction (e.g., SG\&A) & 57 & 11 \\
\hline $\mathrm{N}$ & CAPEX reduction & 43 & 11 \\
\hline
\end{tabular}

Note: All values in percent, percentage of deals with either margin growth above or below sector, which started one of subinitiatives during the first 100 days

1 Only organic deals with margin percentage point increase (average margin during PE - average margin pre PE ownership) above sector margin percentage point increase during the same time span

2 Only organic deals 